\title{
Dallasaurus turneri, a new primitive mosasauroid from the Middle Turonian of Texas and comments on the phylogeny of Mosasauridae (Squamata)
}

\section{G.L. Bell Jr. ${ }^{1, *} \&$ M.J. Polcyn ${ }^{2}$}

1 Guadalupe Mountains National Park, Salt Flat, Texas 79847, USA.

2 Shuler Museum of Paleontology, Southern Methodist University, Dallas, Texas 75275, USA.

* Corresponding author. Email: gbell@dellcity.com

Manuscript received: December 2004; accepted: January 2005

\begin{abstract}
A new genus and species of primitive-limbed mosasauroid, Dallasaurus turneri, from the Middle Turonian ( 92 Ma) of north-central Texas, is described on the basis of two incomplete skeletons. The new taxon retains plesiomorphic characters such as facultatively terrestrial limbs (plesiopedal) but also exhibits certain characters shared with derived mosasaurs of the subfamily Mosasaurinae. In phylogenetic analysis, the new taxon reconstructs as the basal member of that clade. Other plesiopedal taxa previously included in the family Aigialosauridae reconstruct in basal positions within three different, major clades that include members that achieved the derived (hydropedal) fin-like limb condition. In addition, Opetiosaurus and Aigialosaurus reconstruct as successive outgroup taxa to all other mosasauroids, thereby demonstrating the paraphyletic nature of the current concept of Aigialosauridae. Interpretation of our phylogenetic analysis suggests that three different lineages of mosasauroids independently achieved the derived mosasaur body plan, including fully marine limb modifications culminating in the development of flippers or paddle-like appendages. The inclusion of plesiopedal forms within lineages of well-established hydropedal clades requires a reorganisation of our concepts of Mosasauridae to include these basal forms. In order to avoid continued use of the paraphyletic taxon 'Aigialosauridae' as currently defined, we recommend 'Aigialosauridae' as a formal taxonomic name be used only for inclusion of Aigialosaurus dalmaticus and potential members of its own independent lineage. This also avoids the implicit polyphyletic use of 'Mosasauridae'. Additionally, the diagnosis of Mosasauridae should be modified to exclude limb characters that discriminate between more terrestrial versus more aquatic adaptations.
\end{abstract}

Keywords: Aigialosauridae, aquatic adaptation, Dallas aigialosaur, Mosasaurs, Cretaceous, Turonian

\section{Introduction}

Much of our knowledge of mosasauroid interrelationships is based on specimens that have achieved highly optimised marine adaptations, including large size, specialised skull modifications for feeding, extensive modifications of the tail for use as a propulsive organ, and limbs that have evolved into flippers or paddle-like appendages. These ecological adaptations are herein referred to as hydropedal. Mosasaur fossils are best known from Coniacian through Maastrichtian sediments and until recently, knowledge of the record of pre-Coniacian hydropedal mosasaurs was poor, documented only by a small number of fragmentary specimens (Telles Antunes, 1964; Martin \& Stewart, 1977; Páramo, 1994). Previous assignments of taxa to Mosasauridae have been predicated only upon the basis of recognition of distinctive aspects of this highly derived hydropedal morphology.

The family Aigialosauridae was erected to include forms that are clearly related to the fully marine mosasaurs on the basis of certain cranial characteristics, but which retained a small size, slightly modified swimming tail and relatively primitive limb condition. This conservative ecologically adaptive grade is herein referred to as plesiopedal. Included are primitive forms from the Adriatic region long considered members of the 
subfamily Aigialosaurinae (Kramberger, 1892; see also Kornhuber 1873, 1893, 1901; Calligaris, 1988; Carroll \& DeBraga, 1992, DeBraga \& Carroll, 1993, Caldwell et al., 1995). In many cases, the plesiopedal condition was the basis for unquestionable assignment to Aigialosauridae and for the concept of that family or clade as a natural monophyletic grouping. The retention of primitive limbs in part, and poor preservation of cranial details to a greater degree, contributed to poor resolution in previous phylogentic analyses (Carroll \& DeBraga, 1992; DeBraga \& Carroll, 1993; Caldwell et al., 1995). Most of these studies reconstruct these forms as a basal polytomy, or poorly resolved basal cluster, and thus perpetuated the concept of a monophyletic Aigialosauridae. Conversely, the specialised marine adaptations and highly derived nature of later, larger forms was taken as strong evidence of their monophyly. Recently, however, phylogenetic analysis provided evidence that Aigialosauridae is paraphyletic (Bell, 1993, 1997), therefore Mosasauroidea, the name historically given to the superfamily, was used in that study to refer to both plesiomorphic (plesiopedal) and derived (hydropedal) taxa and we follow that usage here.

Bell \& Von Loh (1998; see also Polcyn et al., 1999) used the terms 'aigialosaur-grade mosasauroid' to refer to specimens assignable to the plesiopedal condition and 'mosasaur-grade mosasauroid' to refer to specimens assignable to the hydropedal condition. We define here the new terms describing these adaptive grades for the purposes of clarity and potential use in taxonomic diagnoses. We accept that use of these terms will not be unequivocally useful in all cases for codifying morphology; nonetheless, we believe the new terminology is unburdened by phylogenetic context and thus superior to continued use of the taxon name 'Aigialosauridae' or the term 'aigialosaur-grade mosasaurs' to refer to plesiopedal forms. Additionally, the terms 'plesiopedal' and 'hydropedal', or some variation thereof, may also find application among workers studying other secondarily aquatic groups.

Plesiopedal mosasauroids are generally rather small and possess limbs in which the propodial elements remain elongated, generally constituting one-half or more of the full length of the osseous limb; the mesopodial elements are not expanded; the epipodials are all short and cylindrical with articulations that restrict range of lateral movement; the unguals reflect a morphology capable of terrestrial function. Hydropedal mosasauroids (traditional mosasaurs) are relatively large and possess limbs in which the propodial elements are significantly shortened, stout, and constitute less than one-half of the full length of the osseous limb; the mesopodial elements are flattened and broadened in the transverse and axial limb direction; the epipodials are greatly elongated, dorsoventrally compressed at least on the proximal and distal ends, and their articulations are essentially planar; the unguals are short tapered rods that may be also compressed proximally.

In recent years, discovery and documentation of new Cenomanian and Turonian mosasauroids from the Middle East
(Polcyn et al., 1999, 2003), north and west Africa (Telles Antunes, 1964; Lingham-Soliar; 1994; Bardet et al, 2003), Colombia (Páramo, 1994, 2000) and Texas (Bell, 1993, 1997; Bell \& Polcyn, 1995; Bell \& VonLoh, 1998; VonLoh' \& Bell, 1998) has required reassessment of mosasauroid ingroup relationships using an expanded data set. In the present paper we will first name and describe a new plesiopedal mosasauroid from north-central Texas, then present a phylogenetic analysis including the new taxon and other recently described Cenomanian and Turonian mosasauroids, and finally, discuss the taxonomic implications of the results of phylogenetic analysis.

\section{Age and geological context}

The fossils of two individuals of a plesiopedal mosasaur were recovered from the Arcadia Park Shale approximately $15 \mathrm{~cm}$ above the Kamp Ranch Limestone (Polcyn \& Bell, 2005, Fig. 1). This interval is probably within the upper limits of the Collignoniceras woollgari Zone (lower Middle Turonian), and at least ten metres below the lowest known occurrence of ammonites characteristic of the Prionocyclus hyatti Zone (upper Middle Turonian); it is consequently assigned a date of $92 \mathrm{Ma}$. For a more detailed account of the locality and its biostratigraphic correlation see Jacobs et al. (2005a, b).

\section{Systematic palaeontology}

Abbreviations - TMM - Texas Memorial Museum; DMNH - Dallas Museum of Natural History; SMU - Shuler Museum of Paleontology, Southern Methodist University.

Order Squamata

Superfamily Mosasauroidea

Family Mosasauridae

Subfamily Mosasaurinae

Genus Dallasaurus gen. nov.

Type species - Dallasaurus turneri sp. nov.

Holotype - TMM 43209-1, a fragmentary disarticulated skull and significant portions of a postcranial skeleton in the collections of the Vertebrate Paleontology Laboratory of the Texas Memorial Museum at the J.J. Pepper Research Center, University of Texas at Austin, Austin, Texas (USA).

Referred specimen - DMNH 8121-8125, 8127-8141, 8143-8149, 8151-8157 and 8161-8180, a fragmentary disarticulated postcranial skeleton in the collections of the Dallas Museum of Natural History, Dallas, Texas (USA).

Etymology - After Dallas County, where the specimens were found, and the Greek sauros (lizard). 

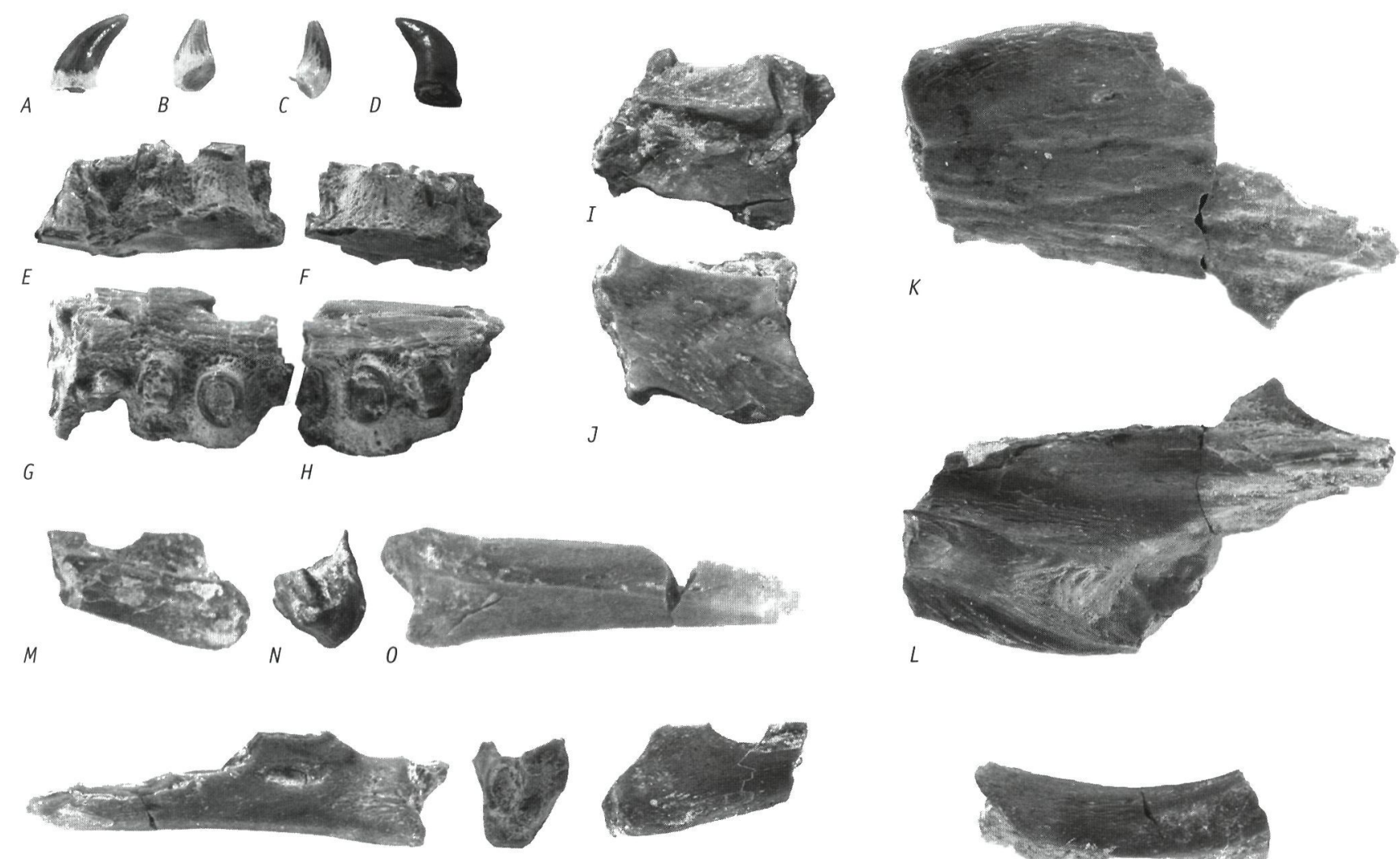

$P$
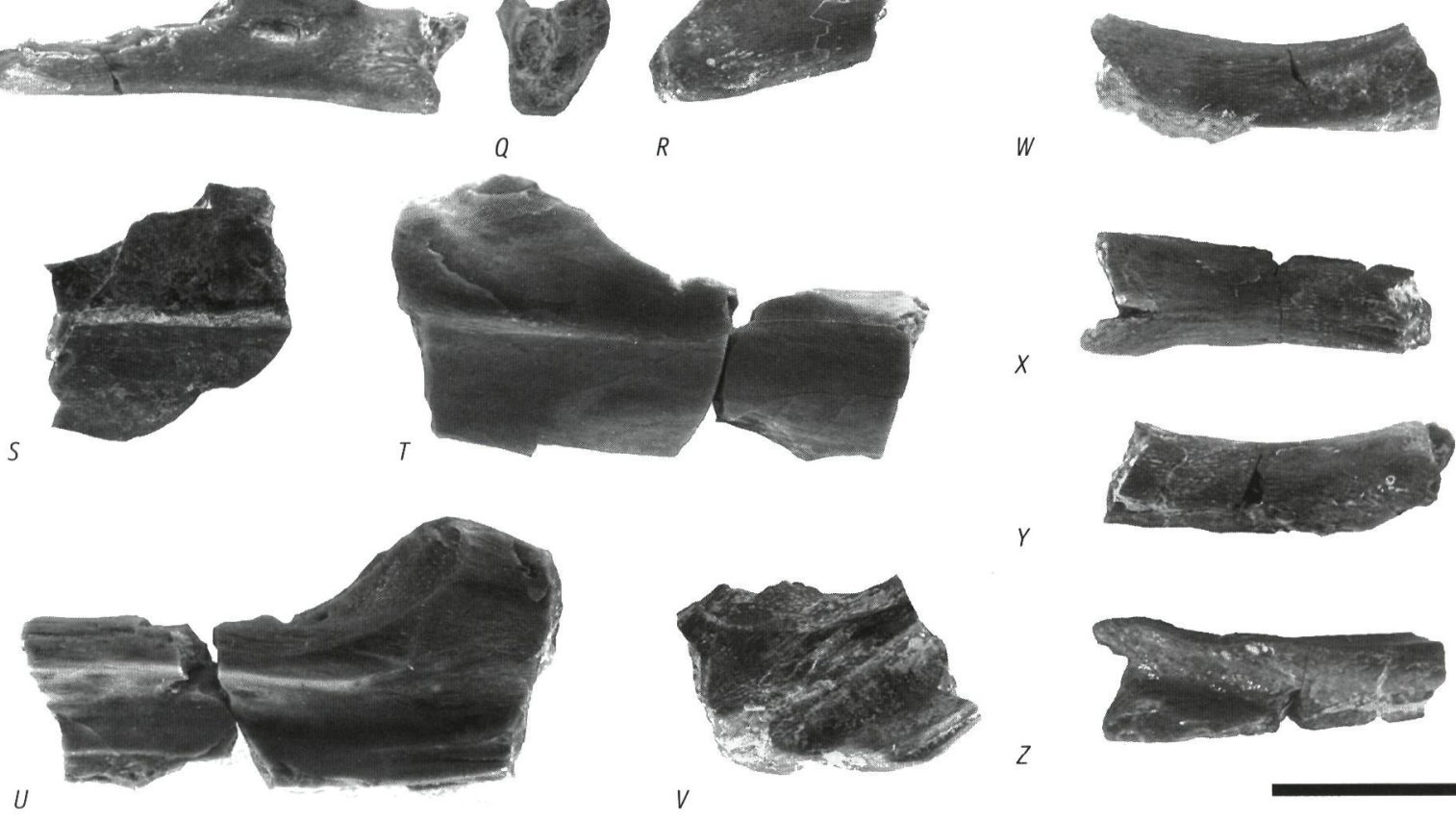

W

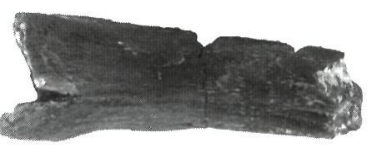

$x$

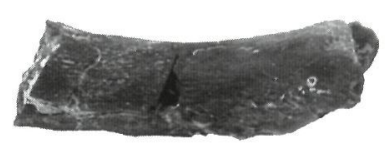

r

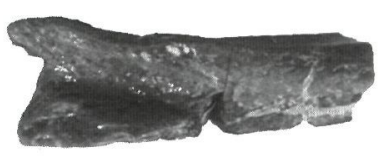

Fig. 1. Cranial elements of Dallasaurus turneri (TMM 43209-1); A - D - teeth of indeterminate positions illustrating range of tooth morphology; $E-H$ - maxilla fragments in $(E, F)$ medial and $(G, H)$ occlusal view; $I, J$ - parietal fragment in (I) ventral and (J) dorsal view; $K, L$ - medial frontal fragment in $(K)$ dorsal and $(L)$ ventral view; $M, N, R$ - angular in $(M)$ lateral, $(N)$ anterior and $(R)$ medial view; 0 - $Q$ - splenial in $(O)$ lateral, $(P)$ medial and $(Q)$ posterior view; $S, V$ - right surangular fragment in $(S)$ lateral and $(V)$ medial view; $T, U$ - left surangular fragment in $(T)$ lateral and $(U)$ medial view; $W$ - Z - left anterior coronoid fragment in $(W)$ lateral, $(X)$ dorsal, $(Y)$ medial and $(Z)$ ventral view. Scale equals $1 \mathrm{~cm}$.

Type locality, horizon, and age - SMU locality number 259 (= TMM locality 43209), Cedar Hill, Dallas County (Texas); Arcadia Park Shale, approximately $15 \mathrm{~cm}$ above the Kamp Ranch Limestone, probably in the uppermost part of the Collignoniceras woollgari Zone (Middle Turonian).
Diagnosis - Small, plesiopedal mosasauroid possessing the following autapomorphies: posterior maxillary teeth strongly recurved posteriorly, slightly inflated at the crown and bearing only posterior carinae that is slightly offset laterally; atlas neural arch mediolaterally compressed but not flattened at its base, condylar surface irregularly figure-eight-shaped; cervical 
vertebra synapophyses protrude below the level of the ventral edge of the centrum (also shared with Halisauromorpha); short, wide fossa excavated immediately below the ventral rim of the cotyle of at least one middle cervical vertebra; hypapophysis anteroventral edge terminating in short projections of irregular length; postglenoid process capped by bony epiphysis bearing a calcified cartilage apex. Synapomorphies with Mosasaurinae: short medial invasion of the parietal table by prongs of the frontal; surangular with steep buttress posterior to coronoid suture; marginal teeth and lacking medial vertical striae; atlas synapophysis long and pedunculate; trunk vertebrae elongate behind synapophyses; vertebral condyles become equi-dimensional posteriorly; at least thirty-four presacral vertebrae; caudals with fused haemal arches; scapula dorsal blade relatively wide, with endochondral articulations smooth and an incipiently interdigitated periosteal suture with coracoid; humerus with large post-glenoid process; ilium distinctly spike-shaped, round in dorsal cross section, dorsal shaft points anterodorsally; acetabular elements tightly adpressed but unfused, articular surfaces finished in smooth endochondral bone. Plesiomorphic characters: supraorbital constriction of frontal, olfactory groove large and broadly rounded in cross section and with broad descending process; dentary with Meckel's groove open medially at about midlength and closed anteriorly; marginal teeth with typical pleurodont tooth implantation and small bony base of attachment; body of cervical vertebral centra relatively dorsoventrally compressed; well-developed zygosphenes and zygantra extend far posterior; three pygal vertebrae; humerus elongate and at least three times greater than distal width, single deltopectoral crest, articular condyle capped by relatively large meniscus of calcified cartilage, suture between diaphysis and proximal epiphysis distinct but fused internally, distal end of humerus bears a calcified cartilage cap for the radial and ulnar facets; femur elongate, calcified cartilage caps on its distal articular surfaces, fibular facet oriented posterodistally. Characters shared with derived mosasauroids, but whose phylogenetic distribution remains uncertain: frontal with broad, shallow, sublongitudinal ridges on dorsal surface (shared with Clidastes liodontus), frontoparietal suture strongly overlapping with obliquely oriented grooves and ridges (shared with all hydropedal mosasauroids except Halisauromorpha); coronoid with distinct dorsolateral cleft, medial and lateral descending wings equally deep (shared with many lineages of hydropedal mosasauroids); no strong or expanded transverse processes for support of ilium (shared with all hydropedal mosasaurs).

\section{Dallasaurus turneri sp. nov.}

Etymology - In honour of Van Turner, who discovered and donated the first specimen and facilitated the donation of the second one.
Diagnosis - As for genus.

Description - Two partial skeletons are used for the purpose of this description, the more complete of the two, TMM 43209-1, as the primary source, the other providing details or validation of observations where required. They were recovered by local fossil collectors from an ephemeral housing construction site that is now completely covered.

The more complete specimen (TMM 43209-1), was found weathering at the surface approximately $100 \mathrm{~m}$ from the DMNH specimen at the same horizon. The first collection was made from that discovery. Subsequent screenwashing from a small area of fluvial fan below this individual yielded several additional elements.

The less complete specimen consists of many individually numbered fragments most likely belonging to a single individual given their preservation, correlative size, and proximity of discovery. According to the amateur collector who discovered the specimen, all of the pieces were found during a several month interval by surface collecting within a few metres of a narrow utilities ditch. The specimens were originally numbered as individual items because they were not found articulated. The number gaps represent intervals between collecting trips when different specimens were placed into the museum's collections. The sequences of numbers assumed to belong to this individual include DMNH 8121$8125,8128-8141,8143-8149,8151-8155,8161-8172$, and 8174-8180.

\section{Cranial skeleton}

The skull is fragmentary but does provide a number of diagnostic characters useful for phylogenetic analysis. of its upper portion only portions of the frontal, parietal and maxillae are present. All elements of the mandible are represented, albeit some as small fragments.

Several fragments of both maxillae have been recovered from the site, but most belong to a badly fragmented left maxilla (Fig. $1 \mathrm{E}-\mathrm{H}$ ). An anterior piece of the left shows a very rapid medial taper between what are probably the first and second maxillary tooth positions. Immediately behind and dorsolateral to this taper there is a large foramen for exit of the maxillary branch of the facial nerve (fifth cranial nerve). Anterolateral to this foramen on the dorsolateral edge of the element is a slightly inclined facet for articulation with the premaxilla. There is no indication of the anterior extent of the external nares, but it must have lain posterior to the third maxillary tooth. All these fragments show a very typical pleurodont tooth implantation with a strong, bony base-ofattachment. A single tooth still attached to a small fragment of a maxilla is strongly recurved posteriorly, slightly recurved medially, slightly inflated at the crown base and bears only a 
posterior carinae that is slightly offset laterally. The surface of the crown has a subtle irregular texture but is not facetted nor does it bear any vertical striae on its circumference (Fig. $1 \mathrm{~A}$ - D). A fragment of the posterior terminus of the left maxilla about $1 \mathrm{~cm}$ long exhibits a gradual taper both in height and width as is typical of mosasauroids. Dorsally, there seem to be no distinct sutural rugosities for articulation with the jugal or lacrimal, suggesting a mobile articulation. Three teeth are attached to this fragment, each of them strongly recurved posteriorly, but only slightly so medially. The greatest curvature in lateral view occurs anteriorly about mid-height of the crown. They are swollen slightly at the base of the crowns and possess a posterior carina. Each of the three teeth is attached to the maxilla by a conical bony base of attachment such as is present in each jaw element.

Only a small portion of the left medial area of the frontal is present (Fig. $1 \mathrm{~K}, \mathrm{~L}$ ), preserving a segment from the left edge to barely across the midline. There are broad, shallow, sublongitudinal ridges on the dorsal surface. Ventrally, the midline is marked by a low, broad, anterior ridge that lies within the olfactory groove posteriorly. The olfactory groove is large and broadly rounded in cross section and only barely embraced below by a descending process laterally. The descending process that is preserved is very strong and broad, relatively much more than in any derived mosasaur. The anterior portion of the descending process is terminated by an inclined rugose sulcus that forms a nearly C-shaped depression, open anteriorly. A sharp, thin ridge runs from the outer corner of this sulcus posteriorly along the ventrolateral face of the descending process. The lateral edge is thin, convexly curved from above and indicates that the frontal was narrower in the middle than in front.

A portion of the anterolateral parietal provides very useful characters (Fig. $1 \mathrm{I}, \mathrm{J}$ ). There is insufficient area present to preserve any indication of the size, shape or position of the parietal foramen; however, the sutural areas for the postorbitofrontal and a significant portion of the frontal suture are present. The former consists of a dorsolateral groove subtended by a narrow shelf. Anteriorly, the groove curved gently medially to underlap the anterolateral extremity of the element. The anterior suture with the frontal bears strongly overlapping, obliquely oriented grooves and ridges. These are strongly developed and of the type usually seen in derived mosasauroids. Significant overlap occurs such that fragments of the corresponding ridges from the frontal are preserved in situ in the grooves of the parietal. A strong oblique flange of the parietal almost separates these two frontal ridge fragments and forms an anterior promontory near the dorsolateral corner of the element. Medial to this a frontal ridge invades the dorsal parietal for a significant but incompletely preserved distance. This strong medial invasion of the parietal table by prongs of the frontal is considered to be a reliable mosasaurine character. Ventrolaterally, there is a distinct but incompletely preserved ridge which turns laterally as it approaches the anterior edge of the element and abuts the postorbitofrontal suture.

A short portion of the anterior left dentary is present and contains four and a half tooth positions (not figured). The bony bases of the second and fourth tooth are preserved. These indicate the teeth are distinctly inclined forwards and outwards and are fused mainly to the lateral wall. There is a relatively short, but distinct subdental shelf which forms a broadly open channel for the teeth. The Meckel's canal is closed in the anteromedial dentary, but there is a thin rugose indention which marks its path. Anteriorly, there is a rugose area for ligamentous attachment with the other dentary. Laterally, the dentary is relatively shallow. There are two foramina anterior to the second tooth position. There is also, starting at the third tooth position, a shallow groove on the lateral face. A fragment of the right dentary from a position probably near the middle of the element has an entire superior medial border, indicating that Meckel's groove was open medially at that position.

The posteroventral portion of the right splenial preserves virtually all of the splenioangular contact (Fig. 10 - Q). Laterally, the contact bears a tall, thin, relatively shallow furrow, but medially there is a short, rounded and relatively deep furrow. The ventromedial portion of this medial furrow also bears a short, horizontally oriented furrow. In medial aspect this lower furrow appears as a small cleft superposed by a short prong. Anterior and ventrally to this cleft are several radiating rugosities. The ascending medial wing is only preserved at its base, but begins to rise a short distance anterior to the angular contact, a distance about equal to the depth of the posteromedial splenial. A relatively large, horizontally oval foramen that conducts the mandibular branch of the facial (fifth cranial) nerve is present anteroventrally to this former position. The ventral border is gently concave in lateral view and inflated transversely.

The anterior half of the left coronoid is present (Fig. $1 \mathrm{~W}-\mathrm{Z}$ ). It possesses a short, not deep, but distinct dorsolateral cleft. Lateral to the cleft is a thin wing of bone which protrudes further anterior than the blunt, thick medial wing. The portions of the medial and lateral descending processes that are preserved are about equally deep.

The anterior portion of the left angular bears a short, elevated ridge that would fit into the small horizontally oriented furrow on the splenial (Fig. 1 M, N, R). Ventral to this is a short, shallow triangular groove or sulcus that would accept a matching protrusion from the splenial.

A small portion of the anterior right surangular is preserved and exhibits a significant part of the posterior coronoid suture which is tall and thin as in derived Mosasaurinae (Fig. $2 \mathrm{~S}-\mathrm{V}$ ). Posterior to this position neither the dorsal, posterior nor ventral edges are preserved. 

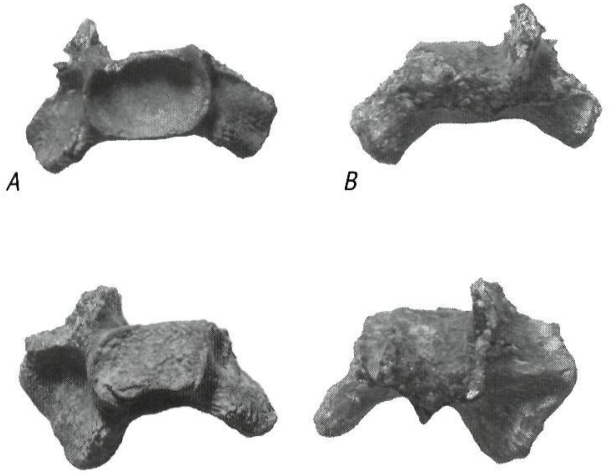

H

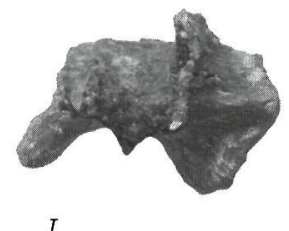

I

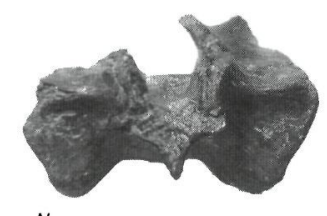

N

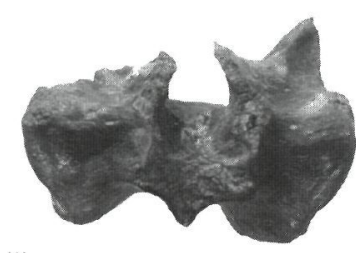

W
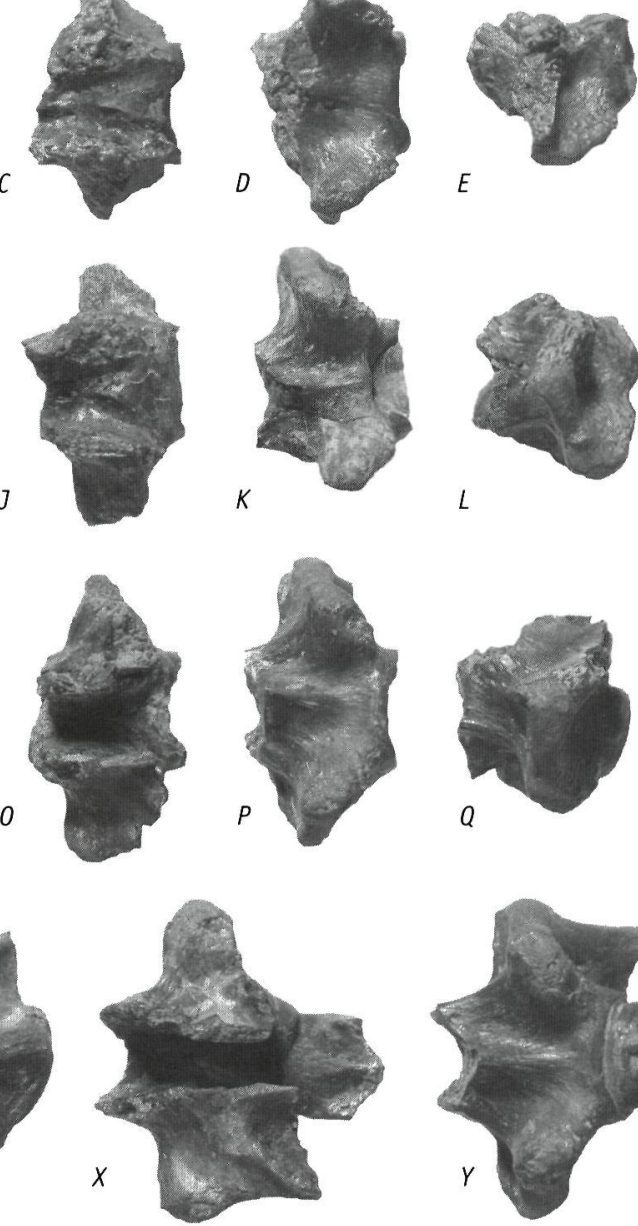

E

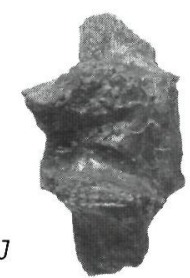

K

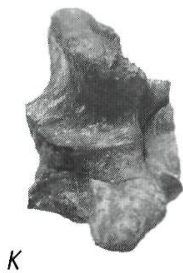

$L$

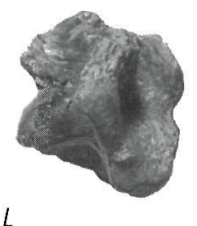

G
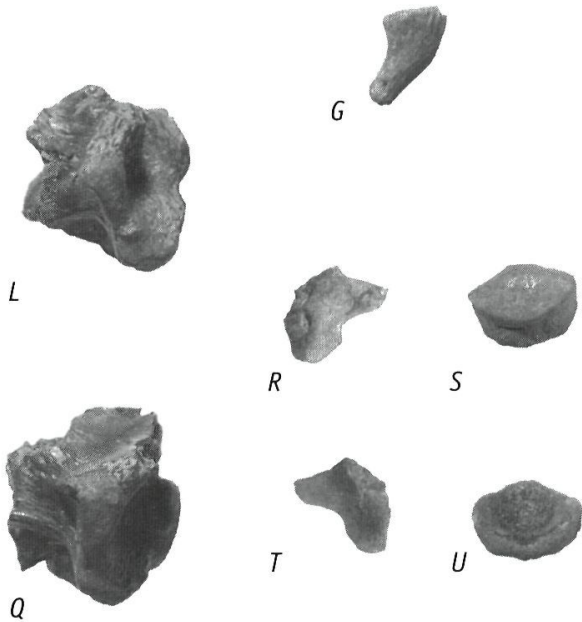

S
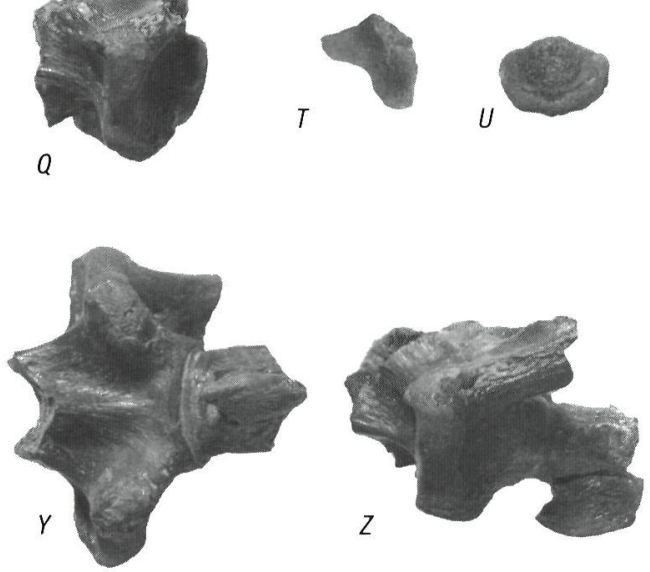

Fig. 2. Cervical vertebra of Dallasaurus turneri (TMM 43209-1); $A$-L anterior to mid-cervical vertebra in $(A, H)$ anterior, $(B, I)$ posterior, $(C, J)$ dorsal, $(D, K)$ ventral, and $(E, L)$ right lateral view; $F-G$ - anterior hypapophysis in ventral and lateral view; $M-Z$ - mid to posterior cervical vertebra in $(M, V)$ anterior, $(N, W)$ posterior, $(O, X)$ dorsal, $(P, Y)$ ventral, and $(Q, Z)$ right lateral view; left atlas neural arch in lateral $(R)$ and anterior $(T)$ views; Scale equals $1 \mathrm{~cm}$.

A small fragment of the posteroventral corner of the right articular is present but is so small as to provide very little information. The low rounded ridge that runs from the posteroventral edge of the glenoid to the posteroventral corner of the bone is present and the rugose ventral edge of the element is obliquely furrowed.

No cranial material was recovered with the DMNH specimen.

\section{Axial skeleton}

There are several fragmentary portions of the cervical series in TMM 43209-1. The atlas centrum and right neural arch are present (Fig. 2 R - U). The centrum is blocky, rounded anteriorly and obtusely pointed posteriorly in dorsal and ventral views. The anterior condylar surface is smoothly and gently rounded ventrally, but dorsally there is a large rounded overhang that gradually curves dorsally and extends onto the dorsal surface as a crescent-shaped, broadly rounded ridge. Posterior to this ridge a semicircular shelf bounds a broad, moderately deeply developed depression that extends to the posterior edge. The ventral articulation for the atlas intercentrum is sublenticular and about half the surface area of the dorsal face. The greatest transverse dimension of the atlas centrum is $6.7 \mathrm{~mm}$, the anteroposterior length of the dorsal surface is $5.2 \mathrm{~mm}$, and its dorsoventral height is $4.2 \mathrm{~mm}$.

The atlas neural arch is missing some of the dorsal flange, but the broken edge suggests that process dorsally was mediolaterally compressed but sub-rounded at its base (Fig. 2 R, T). Medially, the condylar surface is irregularly figure-eight-shaped, being the most constricted at a point just below mid-height. This surface is significantly shorter relative to more derived mosasauroids. There is no posteroventral skirt immediately lateral to the condylar surface, a feature so well developed in most mosasaurines. However, the synapophysis is long and pedunculate, a character which has been assigned as a synapomorphy diagnosing Mosasaurinae. No portion of the axis has been identified.

Definite positions of the posterior cervical vertebrae from TMM 43209-1 cannot be established (Fig. 2 M-Q, V-Z). Fragments include two anterior ends without neural arches or spines, and 
one posterior end still inserted into the cotyle of one of the anterior ends. One fragment, that is probably cervical three or four, has a dorsally incomplete rib articulation and bears a strongly anteriorly deflected ventral portion. Anterior to this deflection the thin rim and ventral surface of the synapophysis has a strongly rugose area for tendonal or ligamentous attachment. The synapophysis protrudes ventrolaterally from the centrum and its ventral edges lie well below the level of the ventral edge of the centrum. A sharp ventral ridge descends rapidly, beginning well behind the anterior edge of the cotyle at approximately the anteroposterior mid-length of the synapophyses. Presumably this would form the leading edge of the hypapophysis, but the entire posterior half of this vertebra is broken away. The main body of the centrum is relatively depressed, being strongly excavated above by a large neural canal which contains two circulatory foramina for central canals. The neural canal is composed of two shallow round-bottomed canals that converge medially near the midlength of the element and then diverge posteriorly behind the foramina for the central canals. The separation between these two canals is formed by an anterior triangular ridge. The cotyle is transversely oval, its width being $7.2 \mathrm{~mm}$ and height being $4.7 \mathrm{~mm}$. In ventral view the ventral edge of the cotyle is very gently concave between its lateral edges.

The anterior half of a more posterior cervical vertebra is identified by its taller and less strongly anteriorly deflected ventral rib articulation of the synapophysis. The ventral edges and ventrolateral face of the synapophysis, as well as the dorsolateral edge, are strongly rugose for attachment of connective tissues. The synapophyses extend well below the ventral edge of the centrum as in the more anterior vertebra. In anterior view the cotyle is obstructed by a fragment of the preceding vertebra having a ventral transverse section that is slightly concave. The cotyle itself is rather deeply undercut ventrally by a thin, wide fossa excavated immediately below the ventral rim of the cotyle (Fig. $2 \mathrm{P}, \mathrm{Y}$ ). This fossa, or transverse groove, is bounded below by a thin ridge connecting the anteromedial edges of the synapophyses. This fossa has never been reported or observed on any other mosasauroid, but does not appear to be the result of a pathology because of it very uniform nature. A ventral median ridge originates at the anterior edge of the ridge bounding the fossa. The cotylar height and width of this vertebra is $4.2 \mathrm{~mm}$ and $6.9 \mathrm{~mm}$, respectively. The dorsoventral dimension of the synapophysis is $7.9 \mathrm{~mm}$.

Another posterior cervical is indicated by a slightly higher and longer rib articulation on the synapophysis (Fig. $2 \mathrm{~V}-\mathrm{Z}$ ). The latter also extends significantly below the level of the ventral edge of the centrum, and the sharp ventral median ridge exhibits the same condition as in the anterior cervical vertebra described above.

The seventh cervical vertebra of TMM 43209-1 is represented only by the posterior half. It is identified by the presence of a hypapophyseal tubercle as opposed to a facet for an articulating hypapophysis, as in other mosasauroids. The tubercle is tall and long but mediolaterally compressed and fully ossified to the posteroventral midline of the centrum. Its posterior edge is protracted to a sharp point posteriorly and its ventral edge gently curved in lateral view. In broken section, the centrum is strongly excavated above by the neural canal. The height of the condyle is $4.9 \mathrm{~mm}$ and its width is $7.1 \mathrm{~mm}$. The dorsoventral dimension of the synapophysis is $7.9 \mathrm{~mm}$.

One cervical hypapophysis associated with TMM 43209-1 was found disarticulated in the screen wash (Fig. 2 F, G). It is unusually long for a mosasauroid. The dorsal articular surface is approximately circular and is bounded anteriorly by a rugose or vertically striated edge. Ventrally, the anterior edge becomes somewhat bevelled and a sharp median crest arises not far below the dorsal articulation. The posterior edge curves slightly backwards also. In lateral view the ventral end tapers significantly and is posteriorly recurved. In anterior view however, the main shaft of the hypapophysis tapers ventrally to about mid-height and then flares slightly ventrally. The ventral edge terminates in about seven short projections of irregular length. The maximum dimension of the hypapophysis is $7.2 \mathrm{~mm}$. The anteroposterior length of the articulation is $4.1 \mathrm{~mm}$, while its width is $3.8 \mathrm{~mm}$.

The DMNH specimen provided only one cervical vertebra, DMNH 8136 (unfigured). It is a posterior portion whose position within the series is undetermined. The hypapophysis is completely fused and in lateral view has a swept-back orientation with a lateral profile that is shaped much like a parrot beak. In horizontal cross-section the hypapophysis is distinctly laterally compressed.

The trunk vertebrae of TMM 43209-1 (Fig. 3 A - I) are represented by three articulated strings containing several vertebrae each, a single disarticulated vertebra, and several partial vertebrae (Fig. $3 \mathrm{~J}-\mathrm{N}$ ). One string consists of nine anterior trunk vertebrae that are mostly complete except for neural spines and most postzygapophyses (Fig. $3 \mathrm{~A}-\mathrm{C}$ ). Another consists of five and one-half centra with synapophyses (Fig. 3 G - I), the last of which fits perfectly with the first caudal vertebra by virtue of a small broken rim of the latter still being attached to the former. By counting only anterior ends, there are at least twenty-four trunk vertebrae represented. There are also three posterior centra which cannot be matched with breaks on anterior halves even though there is sufficient length present (Fig. $3 \mathrm{D}$ - F). This demonstrates that there were originally at least thirty-one presacral (all vertebrae anterior to the first with a long transverse process) vertebrae and probably at least 34. The minimal number is greater than the count for Tylosaurus (30) and Platecarpus (29), and comparable to that of Halisaurus sternbergii (31) (Russell, 1967, p. 76, based on 'Clidastes' sternbergi with 24 dorsals +7 cervicals). However, there is evidence that in Dallasaurus turneri the number is actually greater (34 or possibly more), suggesting 

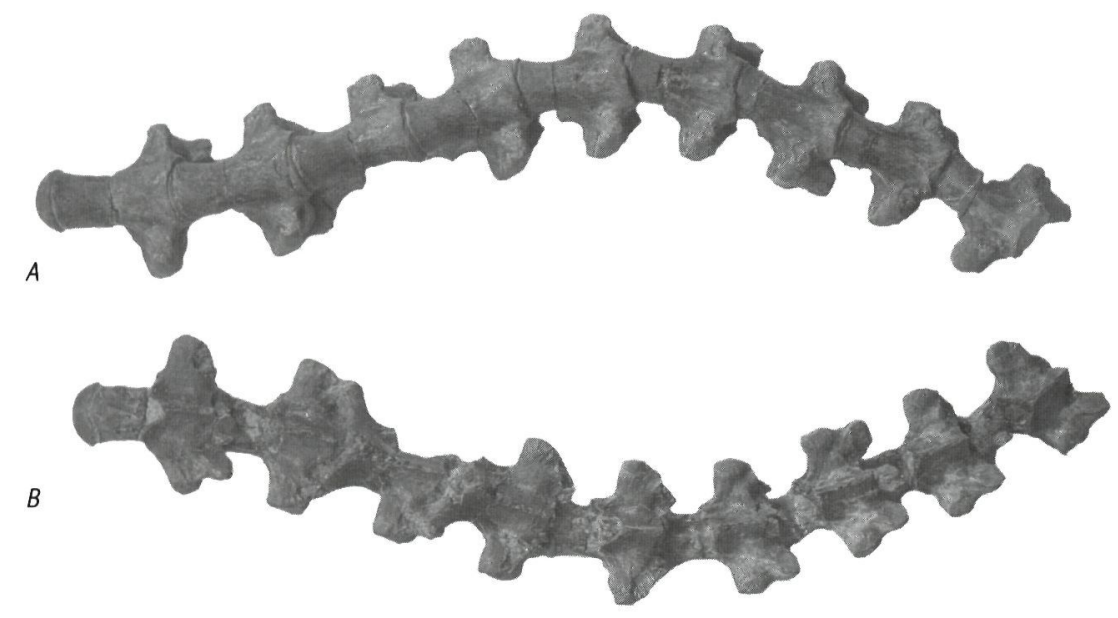

D
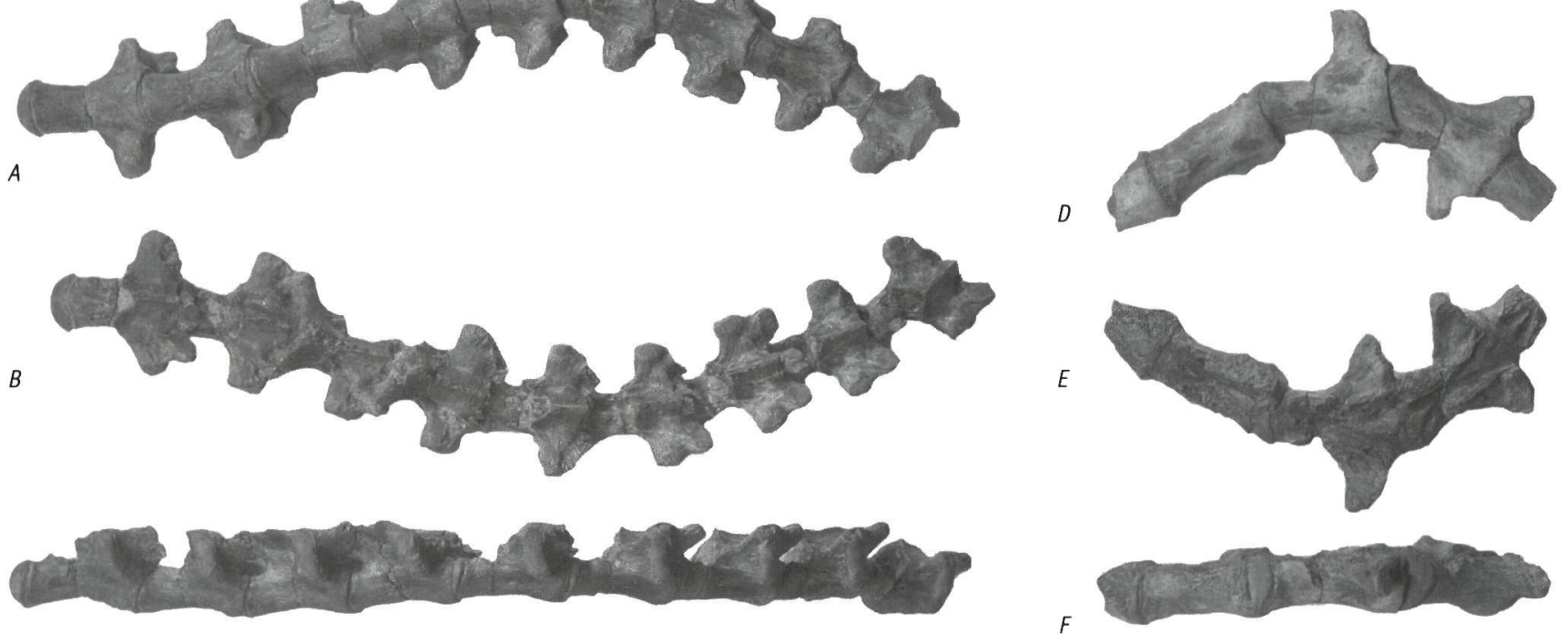

c

G

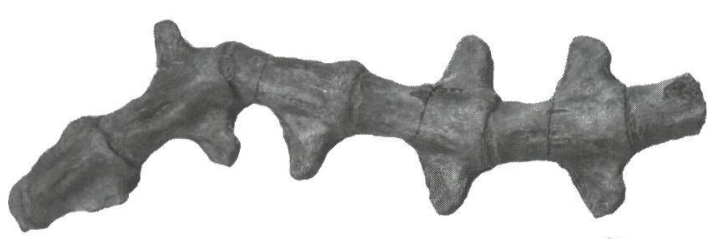

H

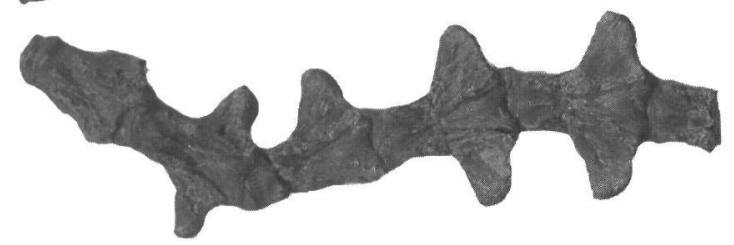

I

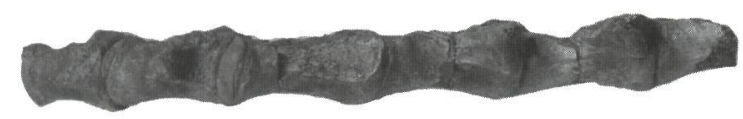

J

K

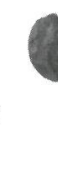

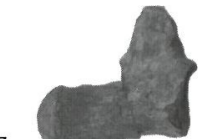

L
M

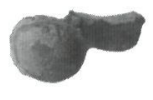

N

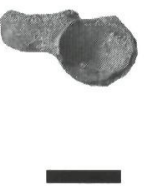

Fig. 3. Trunk vertebrae of Dallasaurus turneri (TMM 43209-1); $A$ - $C$ - anterior trunk vertebrae in (A) ventral, $(B)$ dorsal, and (C) right lateral view; $D$ - I - mid to posterior trunk vertebrae in $(D, G)$ ventral $(E, H)$ dorsal and $(F, I)$ right lateral view; $J-N$ - mid to posterior trunk vertebra in $(J)$ ventral $(K)$ dorsal $(L)$ right lateral $(M)$ posterior and $(N)$ anterior view; Scale equals $1 \mathrm{~cm}$.

that perhaps the count might possibly approach that of mosasaurines.

Generally, the trunk vertebrae increase in length posteriorly to just in front of the sacral region and the slightly depressed condylar articulations become equidimensional and finally slightly higher than wide. The tallest rib articulations occur on the anteriormost trunk vertebrae and gradually decrease in height posteriorly. They also become more posteriorly oriented in that direction.

The first trunk vertebra is represented by its anterior half and is attached to the seventh cervical (not figured). The ventral median ridge begins slightly more anterior in the cervicals, arising less than two millimetres from the anteroventral edge of the cotyle. The synapophyses also descend well below the ventral margin of the centrum. Cross section of the centrum is as described in the cervical series. A significant portion of the neural arch of this vertebra is preserved and, even though broken, the right prezygapophysis is distinctly quite strong.
The articulation for the preceding postzygapophysis is oriented approximately fifty degrees to horizontal. There does not seem to be support for a well-developed zygosphene even though there is a relatively long section of the anteromedial edge of the neural arch preserved above the prezygapophysis. The rib articulation is taller and slightly longer than on any preceding vertebrae and the dorsal portion preserves a small wedge of calcified or secondarily ossified cartilage. On the anterior half of a slightly more posterior vertebra, the ventral median ridge has become very low and obtuse even though its origin can be seen just posterior to the cotylar margin.

The next recognisable trunk vertebra is the first in the articulated string of nine on which the ventromedial ridge is less distinct. On the next vertebra it has disappeared completely (Fig. $3 \mathrm{~A}-\mathrm{C}$ ). On the anterior vertebra of the string of nine, there is no indication of a zygosphene on the well-preserved anterior edge of the neural arch. The first indication of development of a zygopshene is present on the third vertebra 
in the string of nine anterior trunk vertebrae, where the right side of the anterior neural arch has a thickening with a slight overhang. The next vertebra behind this definitely has the thickened base of a zygosphene just dorsomedial to an overhanging crest. There is no doubt that this is a fully formed zygosphene. The last three vertebrae in this string preserve distinctly functional zygosphenes and a zygantrum is visible on the third from last. Prezygapophyses on these nine vertebrae are strong and mediolaterally broad. The articular facets are transversely oval and their lateral edges extend as far laterally as do the synapophyses. The synapophyses of the anterior vertebrae in this string barely, if at all, extend below the ventral border of the centrum. By the fifth vertebra in this string, the synapophyses are significantly higher than the ventral border of the centrum. The first three vertebrae in this string bear strong lateral, rounded ridges that rise from the mid-length of the centrum and expand anteriorly to buttress the posterior face of the synapophyses and also create a pair of ventrolateral sulci between the base of the synapophyses and the median edge of the centra. These disappear posteriorly to these three vertebrae. In TMM 43209-1, the final trunk vertebra has a broken connection to the first caudal vertebra and the two can easily be fitted together even though both are complete (Fig. $3 \mathrm{G}-\mathrm{I}$ ).

Several trunk vertebrae and fragments of the DMNH specimen are in all respects nearly identical to vertebrae from comparable portions of the trunk of TMM 43209-1. In order to avoid repetition, we will describe only two selected examples from the posterior trunk. All have vertical condylar and cotylar faces. Fragments DMNH $8149+8135$ were fitted together during examination to form a single vertebra (not figured). This exhibits a transversely relatively long synapophysis supported by three structural ridges that occupy the posterodorsal, posteroventral, and anteroventral margins. The zygapophysis is broad and almost reaches the lateral articulations of the synapophyses. It is supported by a dorsal, low, radiating ridge. The centrum is constricted anterior to the condyle. The condylar width is $7.8 \mathrm{~mm}$ and condylar height is $6.7 \mathrm{~mm}$, while the lateral centrum length is $15.5 \mathrm{~mm}$. Fragments (DMNH $8165+8176$ ) of a single vertebra from very near the posterior end of the trunk were joined together during examination. They show a very small rib articulation and transversely short synapophysis. The ventral face of the centrum has two narrow, relatively sharp ridges on either side of the midline and a shallow, narrow fossa between. The cotyle is essentially round. The condylar width and height are $6.5 \mathrm{~mm}$ and $7.6 \mathrm{~mm}$, respectively. The lateral centrum length is $13.2 \mathrm{~mm}$.

The first caudal in TMM 43209-1 is distinctly shorter than the last trunk vertebra (Fig. $4 \mathrm{~A}-\mathrm{D}$ ). The transverse processes have no indication of enlargement or buttressing for support of the ilium and pelvic girdle, indicating there was not a normal weight-supporting connection between the vertebral column and the pelvic girdle as in terrestrial lizards and other plesiopedal mosasaurs. The ventral surface of the first caudal is flattened and the broad but incompletely preserved transverse processes point slightly ventrolaterally (Fig. $4 \mathrm{D}$ ). There are three caudals that can properly be called pygals as there are no bases for haemal arches present. The transverse processes of the latter two pygals successively become thinner and broader posteriorly and are oriented more laterally. The transverse process of each pygal is located medially along the internal length of the vertebral centrum. The final pygal has a low rounded ventral ridge. Posterior to this are preserved an incomplete series of 43 caudals with broken ends of fused haemal arches (Fig. $4 \mathrm{E}-\mathrm{Q}$ ). The anteriormost twenty or so of these have a sharp ridge that rises from the medial ventrolateral face of the centrum and runs downwards and outwards along the ventral surface of the haemal arches. Some broken haemals are preserved as incomplete fragments and only consist of the coalesced ventral portions. The bases of the haemal arches arise from the posterior edge of the ventral vertebral centrum. These anteriormost twenty or so caudals with haemal arches have a slight concavity on the vertebral centrum just ventromedial to the base of each transverse process. These concavities also contain one to three small foramina which are the exits for the central canals. Articular faces of the anterior thirty or so caudals are essentially round. No neural arches or neural spines are preserved intact. Screening recovered a few distal portions of neural spines, but these could not be referred with confidence to their original positions. More posteriorly the sharp ridges that descend to the haemals become less pronounced and generally indistinct. A few of the posteriormost caudals as preserved show significant lateral compression.

One pygal vertebra (DMNH 8162) from the DMNH specimen is virtually identical to those from TMM 43209-1. The base of the transverse process is anteroposteriorly wider than high dorsoventrally. It is ovoid in cross section only a short distance laterally from its base and oriented slightly ventrolaterally. The ventral centrum face is impressed and broadly concave. Its condylar width and height are $7.0 \mathrm{~mm}$ and $6.8 \mathrm{~mm}$, respectively. The lateral centrum length is $11.6 \mathrm{~mm}$.

Fragment DMNH $8124+8148$ consists of two and one-half articulated anterior median caudals that were fitted together during examination. Their transverse processes are relatively broad anteroposteriorly at the base and dorsoventrally moderately thin. They are positioned almost at the middle of the lateral face of the centrum. The central faces above and below the transverse processes are slightly concave. The haemal arches are fused with each base preceded by an anteriorly extended, sharp ridge that does not reach the anterior edge of the centrum. The ridges define a narrow, moderately deep fossa on the ventral midline. The neural canals are hourglass-shaped in dorsal view, deeply impressed at midlength where a pair of foramina enter into the right and left central canals. The neural 

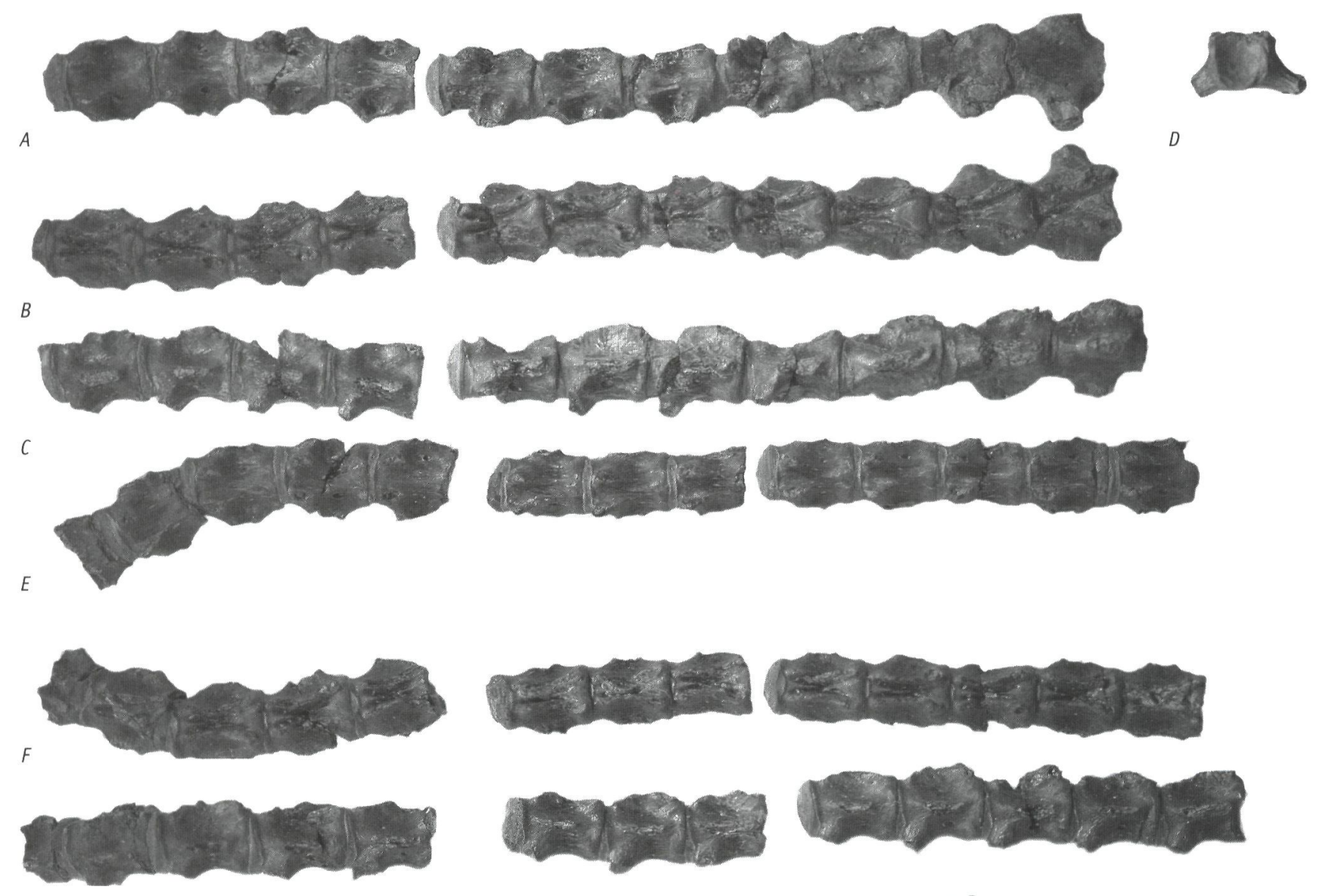

G
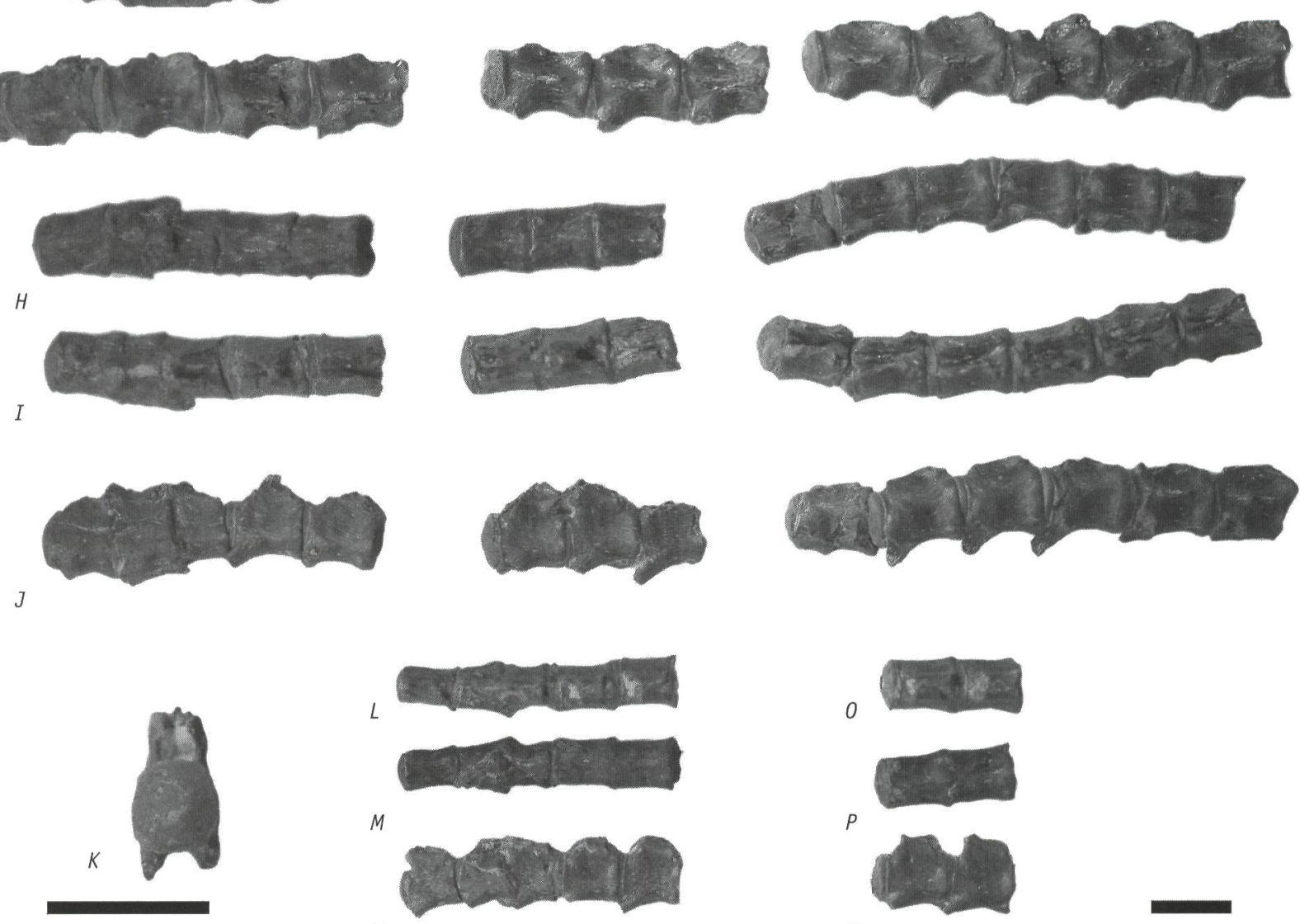

N
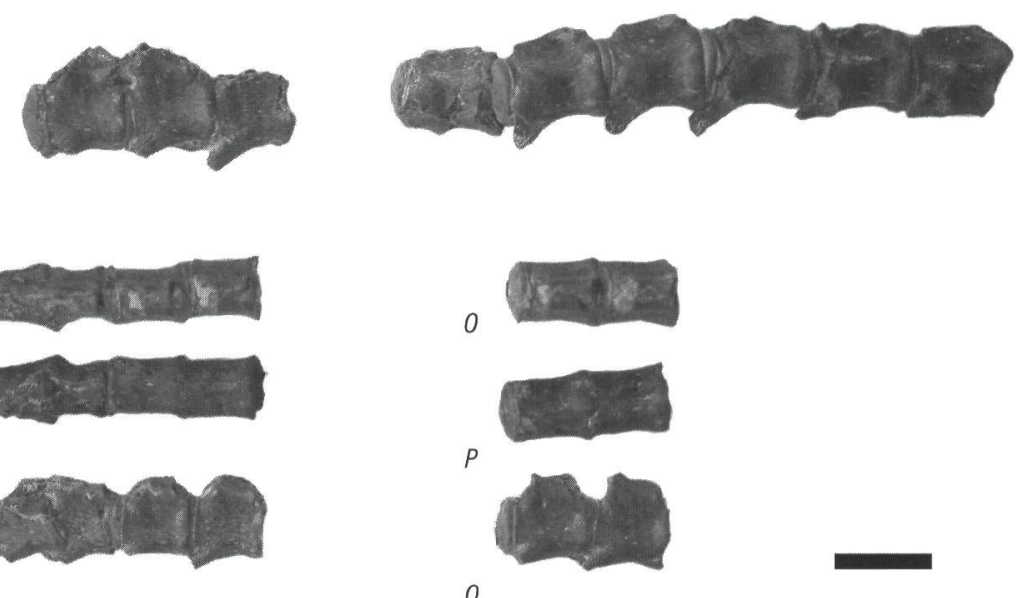

Fig. 4. Caudal vertebrae of Dallasaurus turneri (TMM 43209-1); A - C - anterior caudal vertebrae in (A) ventral, $(B)$ dorsal, and (C) right lateral view; $D$ - first caudal vertebra in anterior view; $E-Q$ - mid to posterior caudal vertebrae in $(E, H, L, 0)$ ventral, $(F, I, M, P)$ dorsal, and $(G, J, N, Q)$ right lateral view; $K$ - posterior caudal vertebra in posterior view. $D$ and $K$ illustrate the range of morphology of the articulating surfaces through the caudal series. Scale equals $1 \mathrm{~cm}$. 
canal is partially divided by a small anteroposterior median septum that essentially disappears near the central canal foramina. The condylar width and height of the posteriormost vertebra are $7.0 \mathrm{~mm}$ and $6.6 \mathrm{~mm}$, respectively, while the lateral centrum length is 10.2 .

\section{Appendicular skeleton}

The only definitely identifiable portions of the pectoral girdle present in TMM 43209-1 are a dorsal blade and an articular portion of a scapula (Fig. $5 \mathrm{G}, \mathrm{H}$ ), probably the right. The dorsal blade is wider than in the generalised lizard condition and probably similar to the Opetiosaurus condition except not
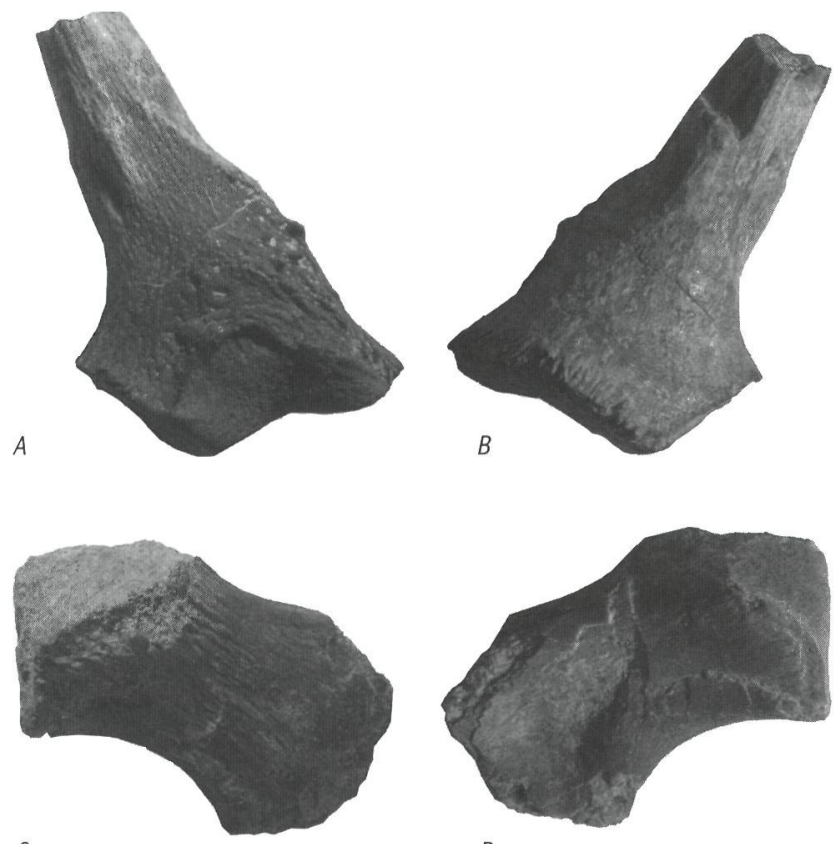

C
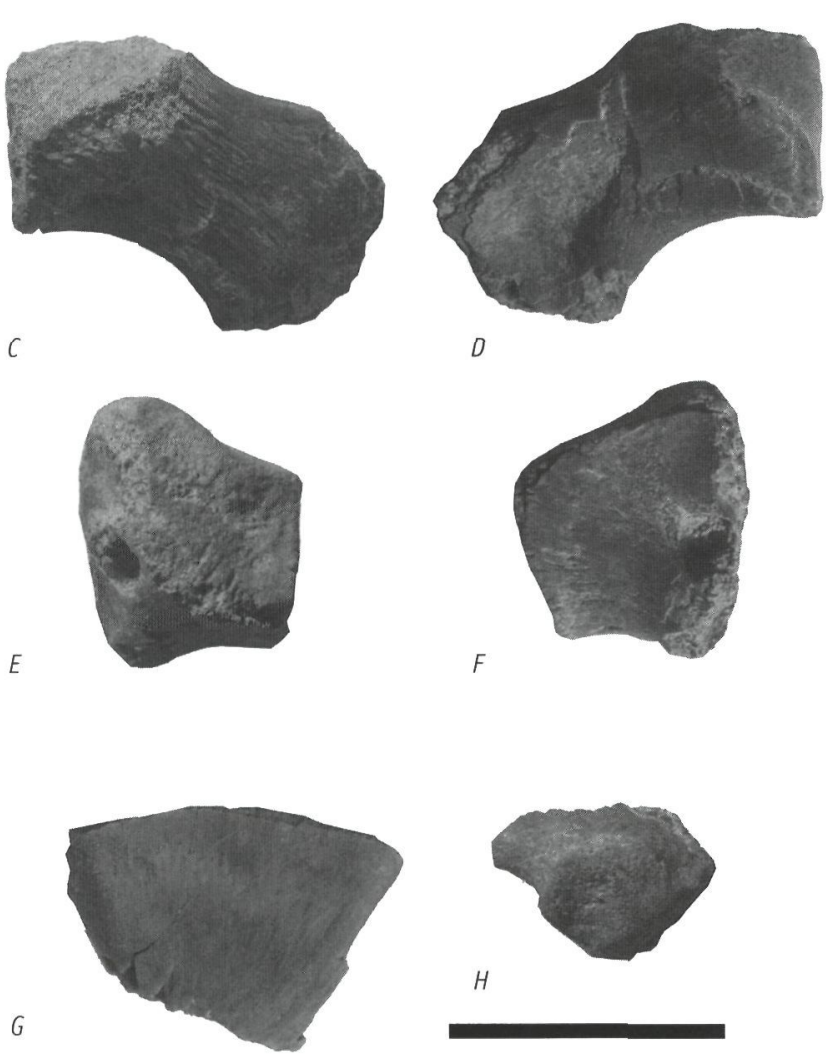

Fig. 5. Pelvic and pectoral girdle elements of Dallasaurus turneri (TMM 43209-1); left ilium in (A) lateral and (B)medial view; left ischium in (C) lateral and $(D)$ medial view; left pubis in $(E)$ lateral and $(F)$ medial view; scapula fragment in $(G)$ lateral and $(H)$ articular view. Scale equals $1 \mathrm{~cm}$. fused to the coracoid. The posterior edge bears some short radial tubercles 5 - $10 \mathrm{~mm}$ ventral to the dorsal edge that are probably the insertion for the M. serratus anterior superficialis (see Russell, 1967, p. 83). The articular portion preserves the glenoid facet that faces ventrolaterally and the coracoid facet, both of which are finished in smooth bone such as the condition in other mosasaurines. The medial edge of the coracoid facet has several rugose ridges of cortical bone that extend beyond the flattened articular surface and are associated with a subtle protuberance of endochondral bone on the articular face for the glenoid. This appears to be the precursor of a much betterdeveloped interdigitating suture between the scapula and coracoid found in other mosasaurines.

The proximal half of the left humerus was found with TMM 43209-1 originally (Fig. 6 B, C, E). Although incomplete, it definitely demonstrates a plesiomorphic condition similar to Opetiosaurus and Aigialosaurus. However, there are some distinct differences from those. There is a single deltopectoral crest capped by a small calcified cartilage tubercle. The crest is situated distal to the articular (glenoid) condyle and is oriented ventrolaterally. The articular condyle (Fig. $6 \mathrm{~B}$ ) is capped by a relatively large meniscus of calcified cartilage. There is a large postglenoid process that is capped by a bony epiphysis bearing a calcified cartilage apex. The suture between the epiphysis and the main body of the humerus is distinct but is apparently well fused, evidenced by its preservation. The distal end of the right humerus was recovered in screening (Fig. 6 F, H, I). It also bears a calcified cartilage cap for the radial and ulnar facets. The later facet is on the posterodistal margin of the bone and is oriented posterodistally. A small, narrow, slightly oblique groove for the radial nerve enters the anterodorsal edge of the bone at a very shallow angle and exits at the anterior margin of the radial facet.

There is the proximal half of an incomplete left humerus among the DMNH material (DMNH 8143; not figured). It is essentially identical to that of TMM 43209-1, except that the postglenoid process and a portion of the posterior length of the element are broken and missing. The deltopectoral crest is structurally like that of the TMM specimen except that the calcified cartilage cap was not preserved with this specimen. A calcified cartilaginous epiphysis is present on the glenoid condyle, but appears to be incompletely fused to the endochondral surface as demonstrated by a deep, narrow groove just proximal to the periosteal margin. It is probable this condition indicates a slightly younger individual than TMM 43209-1. Distally, the element tapers to a narrow sub-cylindrical cross section where it is broken.

The pelvic girdle in TMM 43209-1 is represented by most of both ilia and the incomplete right pubis and ischium (Fig. 5 A - F). The ilia are distinctly spike-shaped as in derived mosasaurids with a round shaft cross section. The dorsal tips are broken away which makes it difficult to estimate their total original length. The pubis is recognised by the foramen that 

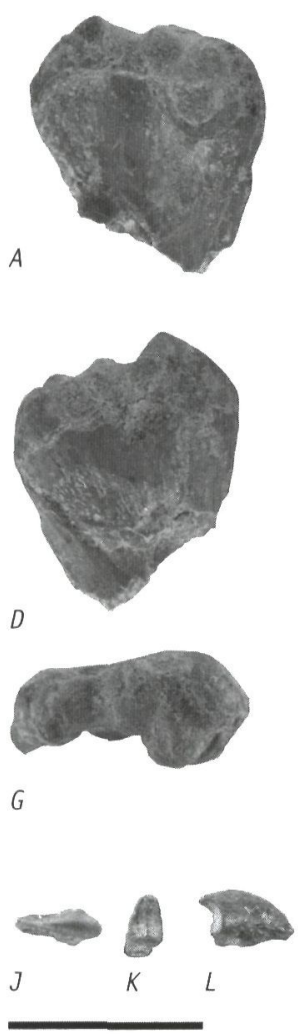

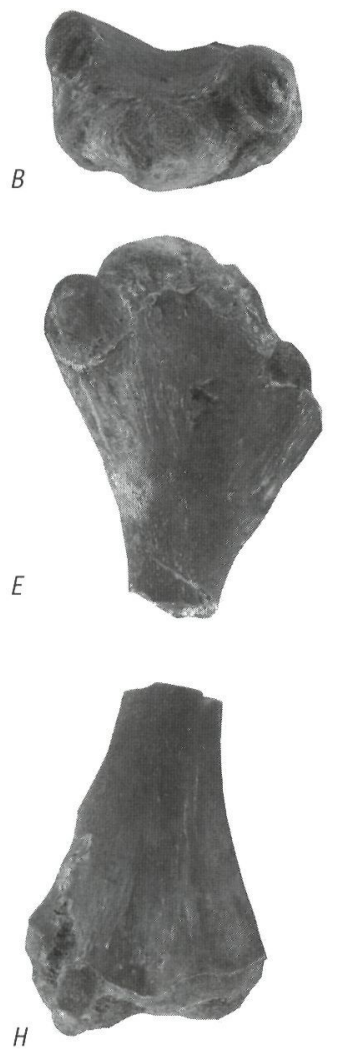

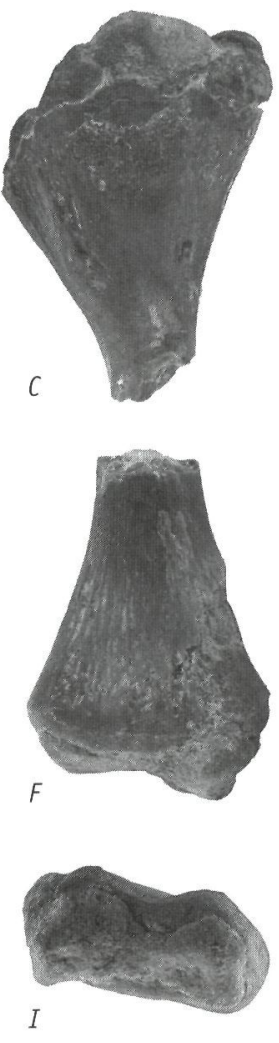

Fig. 6. Limb elements of Dallasaurus turneri (TMM 43209-1); $A, D, G$ - distal right femur in $(A)$ ventral, $(B)$ distal and $(G)$ dorsal view; $B, C, E$ - proximal left humerus in $(B)$ proximal, (C) dorsal and $(E)$ ventral view; $F, H, I$ - distal left humerus in $(F)$ dorsal, $(H)$ ventral and $(I)$ distal view; $J$ - $L$ - ungual in (J) dorsal, $(K)$ posterior and $(L)$ lateral view. Scale equals $1 \mathrm{~cm}$. penetrates through the bone near the acetabulum (Fig. 5 E, F); however, the main medial wing is missing. The ischium is mostly present except for some damage of the ends of the medial wing (Fig. 5 C, D). When the three elements are reassembled to form the acetabulum, three things are immediately obvious. First, the dorsal shaft of the ilium points anteriorly, the probable position in derived mosasaurids. Second, the acetabulum is not fused, but fits closely together along three facets. Third, the articular surfaces are finished in smooth bone. The latter two conditions are present in Mosasaurinae, but not in Russellosaurina (sensu Polcyn \& Bell, 2005).

Most of a left ilium is numbered as DMNH 8147 (not figured). It is identical to the corresponding ilium of TMM 43209-1, including the missing dorsal portion of the iliac shaft, which is round in cross section. There is a denticulate ridge of bone resembling a low cockscomb that rises near the posterior edge of the acetabular depression and climbs about $1 \mathrm{~cm}$ up the posterodorsal margin of the element. The DMNH specimen preserves the acetabular region of a left pubis and a portion of the blade surrounding the obturator foramen (DMNH 8137). The latter is $1.2 \mathrm{~mm}$ in diameter. The articular facets, like those of the ilium, are flat and smooth. The median blade is wider than the acetabular portion where it is adjacent to that structure.

The distal half of the right femur was originally found with TMM 43209-1 (Fig. 6 A, D, G). It corroborates the elongated plesiopedal limb condition seen in the humerus. It too, has calcified cartilage caps on its distal articular surfaces. The fibular facet is oriented posterodistally. Other elements of the limbs are doubtlessly present but are broken or otherwise rendered unrecognisable. One exception is the presence of a single ungual recovered in screening (Fig. $6 \mathrm{~J}-\mathrm{L}$ ). It is like most lizard unguals in being curved, claw-like and in having a crescent-shaped proximal articulation. Recovery of this element is a distinct demonstration of the plesiomorphic condition of the limbs of Dallasaurus. We confidently assign this ungula to the TMM specimen because the only other squamate fossil occurring with these specimens is Coniasaurus, which has unguals that distally are bifurcated and dorsoventrally flattened (MP pers. obs.).

Three additional portions of limb bones are present in the DMNH specimen, but we have been unable to determine their anatomical positions. Both DMNH 8146 and 8155 have one intact articular surface each and their general shapes provide additional evidence of the plesiopedal limb condition. A small area of the endochondral articular surface of DMNH 8146 bears a tiny meniscus of calcified cartilage. Fragment DMNH 8144 is a short portion of the distal end of either a humerus or femur, given its medial diameter and rapid expansion toward the articular end. However, that end is extremely distorted by a pathological condition that caused significant resculpturing of both the periosteal and endochondral bone tissue.

\section{Phylogenetic analysis}

Dallasaurus turneri was scored and included in a data matrix of 144 characters, and 41 taxa, based primarily on Bell (1997) with some corrections, additions and deletions (see Appendix 
A for details). Parsimony analysis was performed using PAUP for Windows version 4, Beta 10 (Swofford, 2002). All characters were treated as unordered and unweighted, and character reconstruction was performed using Deltran optimization.

The analysis produced three equally parsimonious trees with a length of 412, a consistency index (CI) of .430, a homoplasy index (HI) of .570 , and a retention index $(\mathrm{RI})=.757$. Figure 7 illustrates the hypothesis of relationships within Mosasauroidea.

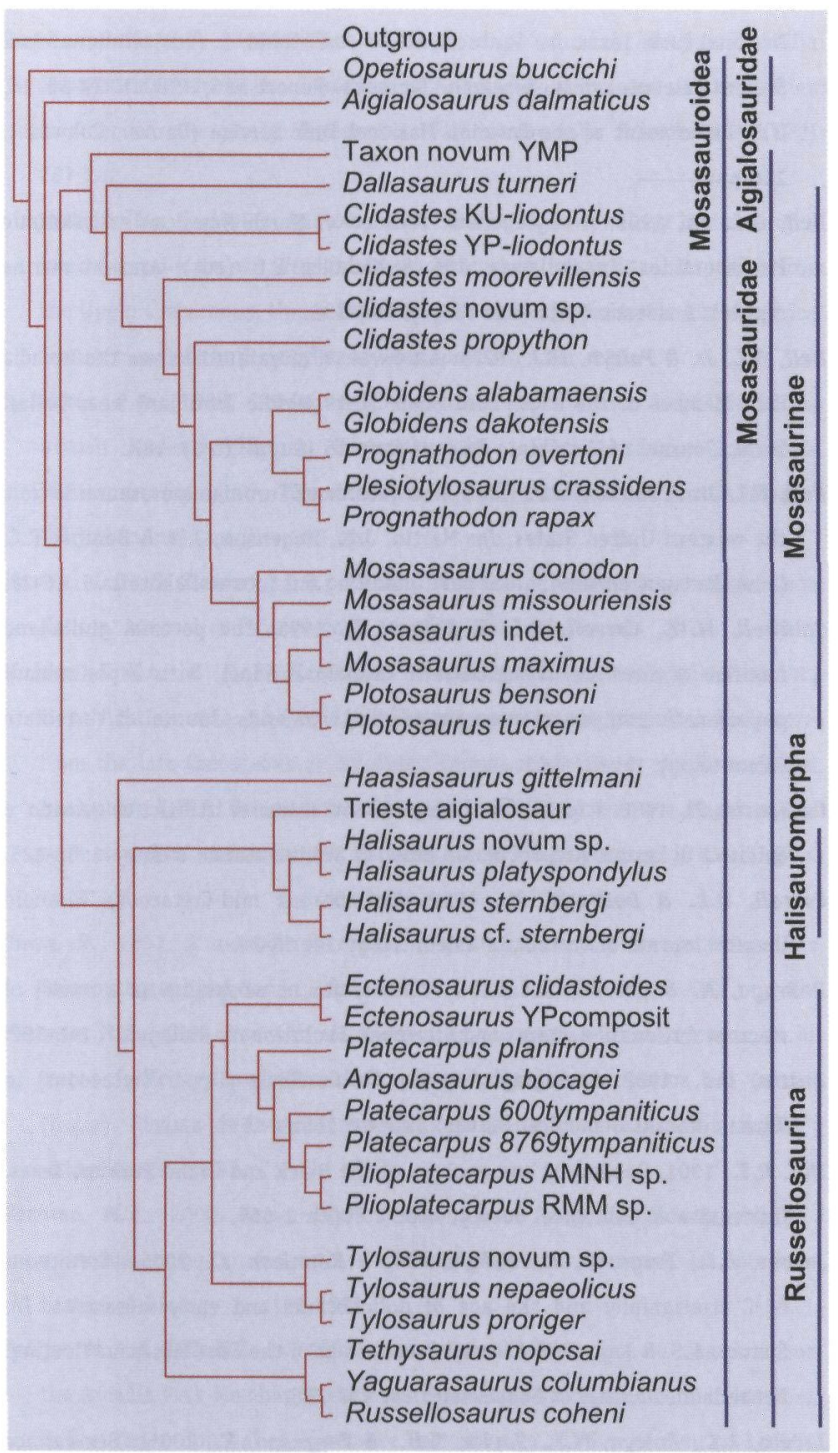

Fig. 7. One of three equally parsimonious trees with a length of 412, a consistency index (CI) of .430, a homoplasy index (HI) of .570, and a retention index $(R I)=.757$ based on an analysis of 144 characters and 41 taxa (Appendix A for details).

Instability of taxic arrangements between the trees was limited to minor rearrangements of specimens of the genus Clidastes. In all trees, Dallasaurus turneri reconstructed as the sister taxon of all taxa traditionally composing Mosasaurinae, and is thus herein referred to that subfamily. Russellosaurus coheni, Yaguarasaurus colombianus and Tethysaurus nopcsai form a clade that reconstructs as the sister group to the clade containing Plioplatecarpinae plus Tylosaurinae, collectively included in the parafamily Russellosaurina (Polcyn \& Bell, 2005). Finally, Halisauromorpha plus the 'Trieste aigialosaur' reconstruct as the sister group to Russellosaurina in all trees, and Haasiasaurus gittelmani was reconstructed as the sister taxon of ((Halisauromorpha + 'Trieste aigialosaur') + Russellosaurina). Opetiosaurus and Aigialosaurus are arranged as successive sister groups to the rest of the ingroup taxa, as opposed to being placed together in a single lineage.

\section{Discussion and conclusions}

The tree produced by the above analysis places taxa retaining a plesiopedal limb condition at the base of each of the three clades whose membership historically included only derived mosasaurs having achieved the hydropedal limb condition. Dallasaurus turneri retains a plesiopedal limb condition and thus would likely have been automatically assigned to the family Aigialosauridae by traditional classification methods, because of similarity of conservative limb morphologies. However, our phylogenetic analysis reconstructs it as the basal member of Mosasaurinae, placed well within Mosasauridae and separated from other plesiopedal mosasaurs. Dallasaurus turneri shares several characters previously considered synapomorphies for derived members of Mosasaurinae. These include invasion of the parietal by medial tongues from the frontal, teeth with smooth medial enamel surface, high coronoid buttress on surangular, interdigitate anterior scapulo-coracoid suture, humeral postglenoid process, elongate atlas synapophysis, sharp anterodorsal ridge on synapophyses, vertically oriented vertebral condyles, elongate posterior thoracic vertebrae, and fused haemal arches. Additionally, the specimen exhibits derived pelvic girdle characters that represent a slightly derived adaptive grade relative to those plesiopedal mosasaroids known from the Adriatic and Middle East.

This analysis provides strong evidence that aigialosaurs and mosasaurs are not sister taxa but are complexly interrelated and suggests that adaptive limb modifications culminating in a flipper or paddle-like condition occurred independently within at least two, or possibly three, different lineages of mosasauroids. Thus, plesiopedal mosasaurs should be considered to represent an ecological and evolutionary grade.

The demonstration that Aigialosauridae is paraphyletic, precludes continued use of the taxon name, at least as it is currently defined, as it has no utility in a phylogenetic sense. This leaves Opetiosaurus bucchichi and Aigialosaurus dalmaticus as the only currently described potential members of a more narrowly defined Aigialosauridae. A phylogenetic reconstruction based on our cladogram retains a separate lineage for these two taxa, placing them as successive sister taxa to the remainder of Mosasauroidea, which would still constitute a paraphyletic Aigialosauridae. We therefore choose to define 
Aigialosauridae as: Aigialosaurus dalmaticus and those taxa more closely related to it than to Mosasauridae. We note here that Caldwell et al. (1995) considered Opetiosaurus bucchichi to be a junior synonym of Aigialosaurus dalmaticus. We have not found support for that conclusion here, but in the event this can be conclusively demonstrated in the future, it would not alter the taxonomic revisions herein made in the definition of Aigialosauridae. Although it is likely warranted, we refrain from revising the diagnosis of Mosasaurinae at this time, pending further phylogenetic analyses utilizing more robust data sets.

Derived members of Mosasaurinae and Halisauromorpha, that is to say those possessing the characteristic flipper derivation of the limb elements (hydropedal), appear in the Coniacian and thereafter. All published reports of derived of pre-Coniacian mosasaurs (Telles Antunes, 1964; Martin \& Stewart, 1977; Páramo, 1994, Lingham-Soliar, 1994; Bardet et al., 2003) retaining diagnostic characters can be referred to Russellosaurina (sensu Polcyn \& Bell, 2005). Additionally, vertebrae possibly referable to a plesiopedal halisaurine mosasaur were reported by Bell \& VonLoh (1998). In this study, Dallasaurus turneri, of Middle Turonian age, is found to be a basal member of Mosasaurinae. Thus, the stratigraphic succession of the major groups of mosasaurs supports our phylogenetically-based conclusion that independent evolution of the hydropedal limb condition occurred at least twice, once within Mosasaurinae, and once within Russellosaurina, and possibly a third time within Halisauromorpha.

\section{Acknowledgements}

We wish to thank Van Turner for donation of the specimens, Scott and Sandy Polcyn for assistance with data entry and figures, and Tony Fiorillo for his enduring patience and goodwill. We also thank Charlotte, the second author's nextdoor neighbour, for allowing us to turn her yard into a muddy bog during wet screening of sediments in an effort to recover additional fragments of the specimen. Finally, we are grateful to Nathalie Bardet and Louis Jacobs for their helpful and constructive reviews.

\section{References}

Adkins, W.S., 1928. Handbook of Texas Cretaceous fossils. University of Texas Bulletin 1838: 1-303.

Bardet, N., Pereda Suberbiola, X. \& Jalil, N.-E., 2003. A new mosasauroid (Squamata) from the Late Cretaceous (Turonian) of Morocco. Comptes Rendus Palevol 2: 607-616.

Bell, G.L. Jr., 1993. A phylogenetic analysis of Mosasauroidea (Squamata). University of Texas at Austin, Texas: 293 pp. (unpubl. PhD thesis).

Bell, G.L. Jr., 1995. Middle Turonian (Cretaceous) mosasauroids from Big Bend National Park, Texas. In: Santucci, V.L. \& McClelland, L. (eds): National Park Service Paleontological Research, Technical Report NPS/NRP01NRTR-95/16, U.S. Department of the Interior, National Park Service (Denver, Colorado): $118 \mathrm{pp}$.

Bell, G.L. Jr., 1997. A phylogenetic revision of North American and Adriatic Mosasauroidea. In: Callaway, J.M. \& Nicholls, E.L. (eds): Ancient marine reptiles. Academic Press (San Diego): 293-332.

Bell, G.L. Jr. \& Polcyn, M.J., 1995. A new basal mosasauroid from the Arcadia Park Member of the Eagle Ford Shale (Late Middle Turonian) near Dallas, Texas. Journal of Vertebrate Paleontology 15 (Suppl. to 3): $18 \mathrm{~A}$.

Bell, G.L. Jr. \& VonLoh, J.P., 1998. New records of Turonian mosasauroids from the western United States. In: Martin, J.E., Hogenson, J.W. \& Benton, R.C. (eds): Partners preserving our past, planning our future. Dakoterra 5: 15-28.

Caldwell, M.W., Carroll, R.L. \& Kaiser, H., 1995. The pectoral girdle and forelimb of Carsosaurus marchesetti (Aigialosauridae), with a preliminary phylogenetic analysis of mosasauroids and varanoids. Journal of Vertebrate Paleontology 15: 516-531.

Calligaris, $\boldsymbol{R}_{\text {., }}$ 1988. I rettili fossili degli 'Strati calcariei ittilitici di comeno' e dell'isola di Lesina. Atti del Museo civico di Storia naturale Trieste 41: 85-125.

Carroll, R.L. \& DeBraga, M., 1992. Aigialosaurs: mid-Cretaceous varanoid lizards. Journal of Vertebrate Paleontology 12: 66-86.

DeBraga, M. \& Carroll, R.L., 1993. The origin of mosasaurs as a model of macroevolutionary patterns and processes. Evolutionary Biology 27: 245-322.

Hattin, D.E., 1962. Stratigraphy of the Carlile Shale (Upper Cretaceous) in Kansas. Kansas Geological Survey, Bulletin 156: 1-155.

Hill, R.T., 1901. Geography and geology of the Black and Grand Prairies, Texas. United States Geological Survey, Report 21(7): 1-666.

Jacobs, L.L., Ferguson, K., Polcyn, M.J. \& Rennison, C., 2005a. Cretaceous $\delta^{13} \mathrm{C}$ stratigraphy and the age of dolichosaurs and early mosasaurs. In: Schulp, A.S. \& Jagt, J.W.M. (eds): Proceedings of the First Mosasaur Meeting. Netherlands Journal of Geosciences 84: 257-268.

Jacobs, L.L., Polcyn, M.J., Taylor, L.H. \& Ferguson, K., 2005b. Sea-surface temperatures and palaeoenvironments of dolichosaurs and early mosasaurs. In: Schulp, A.S. \& Jagt, J.W.M. (eds): Proceedings of the First Mosasaur Meeting. Netherlands Journal of Geosciences 84: 269-281.

Kornhuber, A.G., 1873. Über einen neuen fossilen Saurier aus Lesina. Abhandlungen der kaiserlich-königlichen geologischen Reichsanstalt zu Wien 5: 75-90.

Kornhuber, A.G., 1893. Carsosaurus marchesetti, ein neuer fossiler Lacertilier aus den Kreideschichten des Karstes bei Komen. Abhandlungen der geologischen Reichsanstalt zu Wien 17: 1-15. 
Kornhuber, A.G., 1901. Opetiosaurus bucchichi, eine neue fossile Eidechse aus der unteren Kreide von Lesina in Dalmatien. Abhandlungen der geologischen Reichsanstalt zu Wien 17: 1-24.

Kramberger, K.G., 1892. Aigialosaurus, eine neue Eidechse aus den Kreideschiefern der Insel Lesina mit Rücksicht auf die bereits beschriebenen Lacertiden von Comen und Lesina. Glasnik huvatskoga naravolosovnoga derstva (Societas historico-matulis croatica) u Zagrebu 7: 74-106.

Lingham-Soliar, T., 1992. The tylosaurine mosasaurs (Reptilia, Mosasauridae) from the Upper Cretaceous of Europe and Africa. Bulletin de l'Institut royal des Sciences naturelles de Belgique, Sciences de la Terre 62: 171-194.

Lingham-Soliar, T., 1994. The mosasaur 'Angolasaurus' bocagei (Reptilia: Mosasauridae) from the Turonian of Angola re-interpreted as the earliest member of the genus Platecarpus. Paläontologische Zeitschrift 68(1/2): 287-282.

Lingham-Soliar, T., 1995. Anatomy and functional morphology of the largest marine reptile known, Mosasaurus hoffmani (Mosasauridae, Reptilia) from the Upper Cretaceous, Upper Maastrichtian of the Netherlands. Philosophical Transactions of the Royal Society London B347: 155-180.

Lydekker, R.A., 1888. Catalogue of the fossil Reptilia and Amphibia in the British Museum (Natural History), Part 1. Ornithosauria, Crocodilia, Dinosauria, Squamata, Rhynchocephalia and Proterosauria. British Museum (NH) (London): xxviii + $309 \mathrm{pp}$.

Martin, L.D. \& Stewart, J.D., 1977. The oldest (Turonian) mosasaurs from Kansas. Journal of Paleontology 51: 973-975.

Mulder, E.W.A. \& Mai, H., 2003. Pre-Maastrichtian tetrapods from the Maastrichtian area: the oldest tylosaurine mosasaur (Reptilia: Squamata) from the late Cretaceous of Belgium; Hermann von Meyer (1860) revisited. In: Mulder, E.W.A. On the latest Cretaceous tetrapods from the Maastrichtian type area. Publicaties van het Natuurhistorisch Genootschap in Limburg 44: 19-22.

Owen, R., 1851. A monograph on the Reptilia of the Cretaceous formations. Palaeontographical Society, London. 5: 1-118.

Páramo, M.E., 1994. Posición sistemática de un reptil marino con base en los restos fosiles encontrados en capas del Cretácico superior en Yaguara (Huila). Revista de la Academia Colombiana de Ciencias exactas, fisicas y naturales 19: 63-80.

Páramo, M.E., 2000. Yaguarasaurus columbianus (Reptilia, Mosasauridae), a primitive mosasaur from the Turonian (Upper Cretaceous) of Columbia. Historical Biology 14: 121-131.

Polcyn, M.J. \& Bell, G.L. Jr., 1996. A complete skull of a new mosasauroid from the Arcadia Park Member of the Eagle Ford Shale (Late Middle Turonian) near Dallas, Texas. Journal of Vertebrate Paleontology 16 (Supplement to 3): 58A.

Polcyn, M.J. \&Bell, G.L., 2005. Russellosaurus coheni n. gen., n. sp., a 92 million-year-old mosasaur from Texas (USA), and the definition of the parafamily Russellosaurina. In: Schulp, A.S. \& Jagt, J.W.M. (eds): Proceedings of the First Mosasaur Meeting. Netherlands Journal of Geosciences 84: 321-333.

Polcyn, M.J., Tchernov, E. \& Jacobs, L.L., 1999. The Cretaceous biogeography of the eastern Mediterranean with a description of a new basal mosasauroid from 'Ein Yabrud, Israel. In: Tomida, T., Rich, T. \& Vickers-Rich, P. (eds): Proceedings of the Second Gondwanan Dinosaur Symposium. National Science Museum Tokyo, Monographs 15: 259-290.
Polcyn, M.J., Tchernov, E. \& Jacobs, L.L., 2003. Haasiasaurus gen. nov., a new generic name for the basal mosasauroid Haasia Polcyn et al., 1999. Journal of Vertebrate Paleontology 23: 476.

Russell, D.A., 1967. Systematics and morphology of American mosasaurs. Bulletin of the Peabody Museum of Natural History, Yale University 23: 1-241.

Stewart, J.D. \& Bell, G.L. Jr., 1994. North America's oldest mosasaurs are teleosts. Natural History Museum of Los Angeles County, Contributions in Science 441: 1-9.

Swofford, D.L., 2002. PAUP*. Phylogenetic Analysis Using Parsimony (" and Other Methods). Sinauer Associates (Sunderland, Massachusetts).

Telles Antunes, M., 1964. 0 Neocretácico e o Cenozóico do litoral de Angola. Junta de Investigações do Ultramar (Lisboa): 255 pp.

VonLoh, J.P. \& Bell, G.L. Jr., 1998. Fossil reptiles from the Late Cretaceous Greenhorn Formation (Late Cenomanian-Middle Turonian) of the Black Hills region, South Dakota. In: Martin, J.E., Hogenson, J.W. \& Benton, R.C. (eds): Partners preserving our past, planning our future. Dakoterra 5: 29-38.

Woodward, A.S., 1905. Note on some portions of mosasaurian jaws obtained by Mr. G.E. Dibley from the Middle Chalk of Cuxton, Kent. Proceedings of the Geologists' Association 19: 185-187. 


\section{Appendix A}

The character matrix employed in the phylogenetic analysis was modified from Bell (1997) as indicated below.

10. Frontal width: Modified character to reflect more accurately, the variation seen in frontal length-to-width ratios. Mosasauroid frontals can be separated into three groups that generally have a maximum length to maximum width ratio of about $2: 1$, a group which has a ratio of between 1.5:1 and 2:1, and a group which has a ratio being generally equal to or less than 1.5:l.

0 . element broad and short

1. intermediate dimension

2. or long and narrow

22. Parietal table shape: Modified character to reflect variation if parietal table morphology in basal forms.

0. generally rectangular to trapezoidal with sides converging but not meeting

1. triangular with straight sides contacting in front of suspensorial rami

2. triangular table with poster portion forming parasagittal crest or ridge

34. Character 34 was recoded to correspond to original character description. It was erroneously coded in Bell (1997) inverse of actual states; however, given it is a binary character, it had no influence on the results of that study.

67. Basioccipital canal: Modified to reflect variation seen in basilar artery entrance in floor of basioccipital. In
Yaguarasaurus, Platecarpus planifrons and possibly Angolasaurus, the basilar arteries enter the basioccipital as a pair of foramen, separated by a median septum. In Ectenosaurus, Platecarpus and Plioplatecarpus a bilobate tunnel enters the basioccipital dorsally, passes forwards into the basisphenoid, and exits that bone dorsally and laterally to the braincase. Russell (1967: 148) virtually equates this tunnel with a similarly positioned groove described in Prognathodon. However, more complete preparation of both the type and the only referred specimen of the latter has revealed only small, rounded, blind vestibules not quite symmetrical with the midline and, therefore, of dubious homology.

0 . No canal

1. A small pair separated by median septum

2. A large pair separated by median septum

3. A single bilobate canal

143. Exit for basilar artery from basioccipital: Added character 143 to reflect variation seen in exit for basilar artery from basioccipital:

0. Absent

1. Through two ventral foramina

2. Through single ventral foramina

3. Through two foramina on anterodorsal basisphenoid

144. Posterior thoracic vertebra: Added character 144 to reflect variation in relative length seen in posterior thoracic vertebrae.

0. Posterior thoracic vertebra not markedly longer than anterior thoracics

1. Markedly longer

\begin{tabular}{|c|c|c|c|c|c|}
\hline & 1 & 11 & 21 & 31 & 41 \\
\hline OUTGROUP & $0 ? 0000000 ?$ & 00 ??000??? & $00000 ? ? 000$ & $? 000 ? 0 ? 00 ?$ & 000???0??? \\
\hline Aigialosaurus dalmaticus & ???0?0?102 & 100 ???0??? & $1 ? 10 ? 10 ? 00$ & $? 000 ? 1 ? 000$ & ???2??0??? \\
\hline Dallasaurus turneri & ? ?? ? ? ? ? 0 ? & ?0?? 1 ? 1 ? 10 & ?? ? ?? ? ? ? ? & ?????????? & ?0?????? ?? \\
\hline Opetiosaurus buccichi & $0 ? 00$ ????02 & 100 ?? ?0??? & $10 ? 0 ? ? 0 ? ? 0$ & ?0???0??00 & ???2??0??? \\
\hline Trieste aigialosaur & ? ?? ? ? ? ? ?? & ? ? ? ? ? ? ? ? & ????????? ? & ?????????? & ???20?0? 10 \\
\hline Clidastes KUliodontus & $111000 ? 102$ & $00101 ? 1010$ & $1001111 ? 10$ & ?10021002? & $? 1010 ? 0000$ \\
\hline Clidastes YPliodontus & $111000 ? 102$ & $001 ? 1 ? 1010$ & $1001 ? 11 ? 10$ & ?1002100?? & $? 1010 ? 0000$ \\
\hline Clidastes moorevillensis & 1110000102 & 0010101010 & $1001111 ? 10$ & ? $10021 ? 020$ & $? 1010 ? 0010$ \\
\hline Clidastes novumsp. & 1110000102 & $00101 ? 1010$ & 1001111110 & ?10?210020 & $01010 ? 0010$ \\
\hline Clidastes propython & $111000 ? ? 12$ & 0010101010 & $100111 ? ? 10$ & ?10021?0?? & $? 1010 ? 0010$ \\
\hline Ectenosaurs clidastoides & $1110 ? 0 ? 102$ & $001 ? 1 ? 1020$ & $1110 ? 01 ? 00$ & ? 011110111 & $? 001001 ? 11$ \\
\hline Ectenosaurus YPcomposite & $1010001 ? 02$ & $? 0 ? 1111020$ & $11100 ? 1 ? ? ?$ & ?0?1?0?? 11 & 0001001211 \\
\hline Globidens alabamaensis & ???????? 10 & ?11110101? & ????????10 & ?10??1???? & ? $1010 ? 1111$ \\
\hline Globidens dakotensis & $1110 ? 0 ? 110$ & $111 ? 1 ? 1010$ & $1001 ? 11 ? 11$ & $? 101410020$ & $? 1010 ? 1011$ \\
\hline Halisaurus novumsp. & $1010010 ? 02$ & $00001000 ? ?$ & ???????? 00 & ????0??0?? & $? 1 ? 2001010$ \\
\hline Halisaurus platyspondylus & $1010000 ? 02$ & $11001000 ? ?$ & $10101 ? 0 ? 00$ & ?????11??? & $? 1 ? 2001010$ \\
\hline Halisaurus sternbergi & ???????002 & $100 ? ? ? 0 ? ? ?$ & $0010 ? 00000$ & ????0210?? & ??020?1??0 \\
\hline Halisaurus cfsternbergi & $0 ? 100 ? 0 ? 0 ?$ & ??00?000?? & $0011100 ? ? 0$ & ????02???? & ?00??????? \\
\hline Mosasasaurus conodon & ????? ?? ??? & ? ? ?? ?? ? ? ? & ?? ? ? ? ? ? ? & ?????????? & ?????????? \\
\hline
\end{tabular}


Mosasaurus indet.

Mosasaurus maximus

Mosasaurus missouriensis

Platecarpus planifrons

Platecarpus 8769tympaniticus

Platecarpus 600tympaniticus

Plesiotylosaurus crassidens

Plioplatecarpus AMNHsp.

Plioplatecarpus RMMsp.

Plotosaurus bensoni

Plotosaurus tuckeri

Prognathodon overtoni

Prognathodon rapax

Tylosaurus nepaeolicus

Tylosaurus novumsp.

Tylosaurus proriger

Taxon novumYMP

Yaguarasaurus columbianus

Russellosaurus coheni

Angolasaurus bocagei

Tethysaurus nopcsai

Haasiasaurus gittelmani

MATRIX (Continued)

OUTGROUP

Aigialosaurus dalmaticus

Dallasaurus turneri

Opetiosaurus buccichi

Trieste aigialosaur

Clidastes KUliodontus

Clidastes YPliodontus

Clidastes moorevillensis

Clidastes novumsp.

Clidastes propython

Ectenosaurs clidastoides

Ectenosaurus YPcomposit

Globidens alabamaensis

Globidens dakotensis

Halisaurus novumsp.

Halisaurus platyspondylus

Halisaurus sternbergi

Halisaurus cfsternberi

Mosasasaurus conodon

Mosasaurus indet.

Mosasaurus maximus

Mosasaurus missouriensis

Platecarpus planifrons

Platecarpus 8769 tympaniticus

Platecarpus 600tympaniticus

Plesiotylosaurus crassidens

Plioplatecarpus AMNHsp.

Plioplatecarpus RMMsp.

Plotosaurus bensoni

Plotosaurus tuckeri
$1110 ? 1 ? 111001 ? 1 ? 1011$ 1001?11?11 ?0013100?? ?1?00?001? $111001 ? 100$ 011?1?1011 1002111?11 000131??21 ?1000?0010 $111001 ? 110$ 001?1?1011 1001?11?11 ?00?3100?? ?1000?0010 1010000100 10111?100? 1110?11?00 ??115000?1 0002100110 0?10000?00 111111100? 1111011?01 001?500011 ?002110111 1010?0?100 111?1?100? 1110??1?01 00115?0011 ?002110111 1110?0?111 011?1?1011 1001?11?11 1100411??? ?1110?1011 ???????00 111?1?100? 1113011?01 0001?0??11 0002110??2 ???????00 ??1010100? 1113011??? ?0??????? ?002110012 $101001 ? 010$ 101?1?1011 1011?11111?001110120 01000?0010 1010?1??10 101?1?1011 1011?11111 ?0011101?0 ?1000?0010 101000??10 0110101011 1001?11111 ?101500?20 ?1110?1011 101000??10 0010101011 1001111?11 ?1?041?020 ?1110?1011 121111?000 10101111?? 1000?11101 ?00140???1 10011?0210 12110110001110111011 1001?11?01 ?011410121 10011?0200 1211111000 111?1111?? 1001?11101 10?1410111 00000?0210 $1011 ? 11002$ 10101?01?? 0001?00000 ?0?00000?? ?0011?0?10 0010?0?102 000?1??020 1200?11000 ?0?1300111 1??1100210 $101 ? ? 00 ? 0200011110201200011000$ ?01120?111 1001100210 101 ??0??01 ?11????0?? 1100?1??00 ?0??50???? 1??2100011 1010?0?102 110?1?1020 1200?11000 -0?100??11 ??00100210 ????????? ????????? ????????? ????????? ???11?020?

$\begin{array}{lllll}51 & 61 & 71 & 81 & 91\end{array}$

000?000000 0?0?000?00 0??0000000 ?0?0000?00 0?000?0000 1 1?00?00??? ??0000???? 1??0???010 0??000020? ?010??000? ????????? ???????00 020??001?? ??100002?0 011??00101

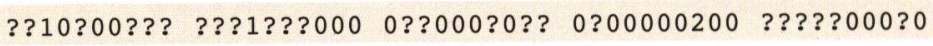
0000000 ??? 10??????? ??????,000 0???????? 111???0?00 $0010001000 \quad 0010100200 \quad 22 ? 1000100 \quad 0 ? 101002010110000001$ 0010001000 001010?100 2??10?01?? ??10100201 0110?00001 $1010001000 \quad 00101002002201000100 \quad 00101002010110000001$ $1010001000 \quad 001 ? 10 ? 200 \quad 2201000100 \quad 00101002010110 ? 00 ? 01$ $1010001000 \quad 0010100100 \quad 2201 ? 10100 \quad 00101002010110000001$ $0110 ? 11000$ ???100?3?? 20?1?00000 ?100110201 ??10010001

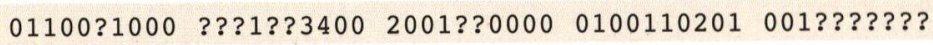
?0?00?1000 001?????? ?2010?1100 0011001101 011??0?0?1 1010001001001 100??? ????????? ??11001101 011?00?0?1 0?????0000 10??00001? 12011000100010000100 ??0?000100 0000000000 100?????? ?201?00010 0010000101 ??0?????0 0000?01??? 10???????? 1??1???010 00??????? ?10??00100

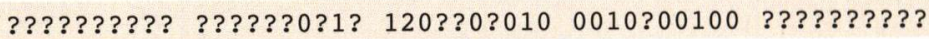
????????? ??????1?? 2201????00 001010021101110010 ? $0101010111100010 ? ? 00$ 220?????? ??10100211 010???10?1 $0101010111100 ? 100300 \quad 22010 ? 1101 \quad 10101002110111011001$ $0010011011100 ? 10 ? 300 \quad 2 ? 01011101 \quad 10101002 ? 1011 ? 0000 ? 1$ $0010000001 \quad 101 ? 00250022001000000100110201 \quad 10100000 ? 1$ 0010000101 101?00351? 2210100000?100100201 100?0000?1 0010000101101100351 ? 2210100000 0?00100201 1011?00001 101??01??? 101 ????200 2??101?100 ??1?0002?1 ?????00001 0010000101 111?00?51? 2210100000 01????0??1 ????????? 00100?0100 11???03??? ?21????000 110010020? ??0??00001 $0001011011100010 ? 101$ ?2?1???101 10000012?? 010?10?011 0001011??1 100?10?101 2??111?101 ?0??????1 ????101011 
Prognathodon overtoni

Prognathodon rapax

Tylosaurus nepaeolicus

Tylosaurus novumsp.

Tylosaurus proriger

Taxon novumYMP

Yaguarasaurus columbianus

Russellosaurus coheni

Angolasaurus bocagei

Tethysaurus nopcsai

Haasiasaurus gittelmani

MATRIX (Continued) OUTGROUP

Aigialosaurus dalmaticus

Dallasaurus turneri

Opetiosaurus buccichi

Trieste aigialosaur

Clidastes KUliodontus

Clidastes YPliodontus

Clidastes moorevillensis

Clidastes novumsp.

Clidastes propython

Ectenosaurs clidastoides

Ectenosaurus YPcomposite

Globidens alabamaensis

Globidens dakotensis

Halisaurus novumsp.

Halisaurus platyspondylus

Halisaurus sternbergi

Halisaurus cfsternberi

Mosasasaurus conodon

Mosasaurus indet.

Mosasaurus maximus

Mosasaurus missouriensis

Platecarpus planifrons

Platecarpus 8769tympaniticus

Platecarpus 600tympaniticus

Plesiotylosaurus crassidens

Plioplatecarpus AMNHsp.

Plioplatecarpus RMMsp.

Plotosaurus bensoni

Plotosaurus tuckeri

Prognathodon overtoni

Prognathodon rapax

Tylosaurus nepaeolicus

Tylosaurus novumsp.

Tylosaurus proriger

Taxon novumYMP

Yaguarasaurus columbianus

Russellosaurus coheni

Angolasaurus bocagei

Tethysaurus nopcsai

Haasiasaurus gittelmani
$10 ? 01 ? 1000001 ? 10030021010111001011001211$ ??????0??1 $10101010001010100 ? 1 ? 21010 ? ? ? 00 \quad 00110012110110 ? 00001$ $1110001000 \quad 001101 ? 4012200000000 \quad 000010021100010000 ? 1$ 1110001001001100040122000000000000100201001100 ?0? $0010001000 \quad 001101040122000100000000100211100 ? 000001$ 00 ????0000 000010 ???? ????????? ??10100200 000?000100 0110000000000100131 ????????? ??00?00100 ??1?????? $0110000000000100121 ? 11001000100100$ ?00100 ????????? $0010000000100100251 ? 22 ? 0100010$ 0100?002?0 ??1?????? 11100?1000 000100111- 1100100010 0000?000-0 ??10?11100 000?????0? ???????000 0101000000 00000001?0 ??10000000

$\begin{array}{lllll}101 & 111 & 121 & 131 & 141\end{array}$

?00?0?00?0 0000??0000 0000000000 000000000? 0000 ???0000??? ??00?01??? 000??00000 00000001?? 0000 $1110 ? ?, 0 ? 1$ ??00?010?? 01?00000?? ????000??? 0?01 ???00?0000 0000?00?00 000?0?0000 00000????? 0000

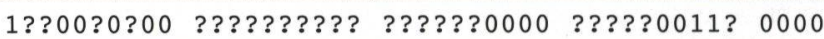
$20101 ? 11110101101000210101112100010100012001$ 20101?1??? ????????? 2101011121 00010????? 2?01 2?101?1111 ??01101000 210101112100010100012001 2110???1?1 ??01101000 2101011121 00010???? 2?01 2?10???1?1 ???????000 2101011121 0?0?????? 2?01 ???0?????? ??01011100 21???00120 10100????? 1031

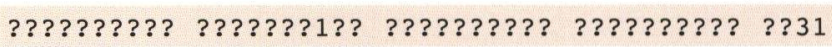
2??0?????? ?????,10?? 21010111 ?? ????????? 2?01 2?10????? ?,??????? ????????? ????,???? ??01

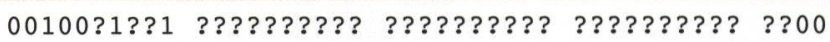
0 ???????1 ????????? ????????? ?????1??? ??00 ???0011101 $01111111001001000010111001111 ? 0000$ 0 ???????? ????????? ????????? ????????? ??00 2011????:1 ???1?01010 31110111?1 ????????? 2?01 2??1????? ????1010?? 311101112100011 ???? 2?01 20?1??1111 ??02101011 311101112100011100012101 20111?1??1 ??01??100? ???????21 00?11???? 2?01 1??0????? ??01011100 20?1100?20 11100????? 1?20 1??0?????0 ????????? ????????? ????????? ??30 $10000010001001011100 \quad 20 ? ? 1 ? 012011100101101030$ 2?10????? ??01101011 $312101112100010 ? ? ? ?$ 2?0? ????????? ??01011100 20?1100120 11100????? 1?30

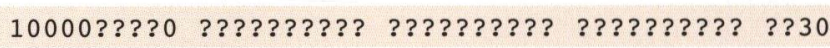
2??1????? ????????? ????????? ????????? ???? 20111???1? ??02101011 311101112100011 ???? 2101 2???????1 ????????? 212101 ?1? ????????? ??01 2110????:1 ??01?01011 2121011121 00010????? 2?01 100?????? ????????? 10?1?0001? 11100???? ??00 1??0????? ??11011101 10?110001? ????????? 1?00 $1000011000101101110110 ? 110001 ? 1110010 ? 001100$ 1 100001??? ????????? ????????? ????????? ??0?

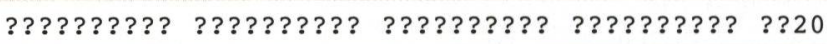

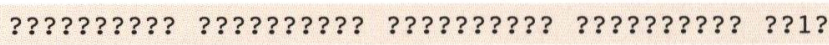

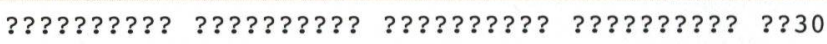
00??????0 ??11101000 ?????011?? ????,0?0?? ???? 1000000?0? ??11101?10 0?00000000 1110000??? 00?? 